\title{
Integrative Effects of Vine Water Relations and Grape Ripeness Level of Vitis vinifera L. cv. Shiraz/Richter 99. I. Physiological Changes and Vegetative-Reproductive Growth Balances
}

Hunter, J.J. ${ }^{12^{*}}$, Volschenk, C.G. ${ }^{1}$, Novello, V. ${ }^{3}$, Strever, A.E. ${ }^{2}$, Fouché, G.W. ${ }^{1}$

(1) ARC Infruitec-Nietvoorbij ${ }^{1}$, Private Bag X5026, 7599 Stellenbosch, South Africa

(2) Stellenbosch University, Department of Viticulture and Enology, Private Bag XI, Matieland 7602, South Africa

(3) University of Turin, Department of Agriculture, Forest and Food Sciences, via L. da Vinci 44, I-10095 Grugliasco, Italy

Submitted for publication: April 2014

Accepted for publication: July 2014

Key words: Grapevine, water relations, canopy, grape ripeness, berry physiology

\begin{abstract}
The water relations and physiological status of the grapevine are critical for obtaining a quality product and for fully exploring vineyard and grape potential. The objective of this investigation was to determine the effect of grapevine water status (induced by means of two field water capacity-based irrigation levels, $75 \%$ and $100 \%$, applied at single and combined vine developmental stages) on morphological and physiological changes in Vitis vinifera L. cv. Shiraz/Richter 99 grapevines and grapes (harvested at different soluble solid levels) under field conditions. The integrative effects of vine water relations and grape ripeness level, specifically in a Mediterranean high winter rainfall area, have not yet been investigated systematically. The terroir affected the reaction of the vines to treatments. The soil displayed high water-holding capacity and a buffer against favourable evapotranspiration conditions, even with a western aspect and being subjected to long and relatively dry seasons, with frequent occurrence of high temperatures and grapevines with fully developed canopies. The vines did not seem overly stressed - in line with the relatively high base soil water fractions of mostly more than $\mathbf{5 0 \%}$ of field water capacity. Primary and secondary leaf water potential and stem water potential displayed similar patterns and the water potential of the primary and secondary leaves was similar. Despite relatively high base soil water contents that prevented excessively low plant water potential and classic leaf and berry behaviour to surface, the vines still responded in a noticeable way to volume and timing of irrigation in relation to the grape ripeness level status. Water relations, ripeness level and terroir conditions showed an integrated, steering impact on physiological, vegetative and reproductive behaviour. Post-véraison irrigated vines were expected to maintain relatively high water potential during the last weeks of the ripening period, but this seemed not to be the case. All vines seemed to have recuperated/stabilised during this time, maintaining their water balances. Physical, physiological and compositional changes in the berry during late ripening under field conditions were clarified further. New information was obtained on the relationships between the behaviour of the root system, canopy and grapes and the changing terroir conditions during the ripening period.
\end{abstract}

\section{INTRODUCTION}

The physiological functioning of the grapevine, growth balances and the capacity to endure stressful conditions over seasons are an integrated response of the variety-rootstock combination to the terroir conditions that are experienced and the vineyard practices that are applied (Smart \& Coombe, 1983; Hunter \& Myburgh, 2001; Hunter \& Bonnardot, 2002; Vaudour, 2003; Deloire et al., 2005a, 2005b; Hunter et al., 2010; Hunter \& Bonnardot, 2011). Healthy vines and continued fertility are required for sustainability, whereas uniform shoot growth and grape development per surface area would favour lower production costs as well as grape and wine quality (Hunter et al., 2010, 2011).

Together with temperature, plant water status is generally recognised as one of the most critical factors affecting the growth balances of the grapevine (Smart \& Coombe, 1983; Coombe, 1987; Hunter \& Myburgh, 2001; Hunter \& Bonnardot, 2011). The gradual depletion of soil water during the growth season normally results in increasing water deficits experienced by the grapevine, which have a direct

\footnotetext{
${ }^{1}$ The Fruit, Vine and Wine Institute of the Agricultural Research Council

*Corresponding author: hunterk@arc.agric.za

Acknowledgements: We would like to thank the Agricultural Research Council and the South African Wine Industry (through Winetech) for funding. The technical support of the Vine Physiology Group in the Viticulture Department of ARC Infruitec-Nietvoorbij is much appreciated. Special thanks also to ARC Biometry, particularly Mardé Booyse, at ARC Infruitec-Nietvoorbij for the elaboration of the data
} 
impact on its capacity to buffer the potentially deleterious effects of adverse environmental conditions. Considering the vegetative and reproductive growth patterns of the grapevine and concomitant water requirements, it follows logically that the volume of accessible water at specific developmental stages during the season may have differential effects on growth as well as the eventual grape and wine quality. This is complicated by the difference in sensitivity of the various physiological processes and plant organs to water deficits (Mohr \& Schopfer, 1995). Optimum irrigation strategies that would allow timely water deficits in order to curb vegetative growth, but at the same time maintain a canopy capacity and microclimate that would benefit the required berry size, grape composition and wine quality (as depicted by different wine styles), directly or indirectly, are still pursued for different terroirs. In view of a changing climate that would leave resources and environmental conditions for grape production more and more marginal in the future, water management will gain even greater importance (Schultz, 2000; Cyr \& Shaw, 2010; Hunter et al., 2010; Schultz \& Stoll, 2010; Hunter \& Bonnardot, 2011).

The supply (via photosynthesis) and loading (into the phloem) of sugar (sucrose) in plant sources, sink hierarchy/ priority, phloem transport and unloading in sinks (such as the grape berry) after partitioning, as well as metabolism of sugar in sinks, are critical events in the grapevine growth cycle (Hunter et al., 1994; Hunter, 2000; Hunter \& Ruffner, 2001). Despite many attempts based on, e.g., berry dimension responses (after transport disruption by means of girdling and heat treatment) (Lang \& Thorpe, 1989; Greenspan et al., 1994, 1996), flow of water-soluble dyes (Düring et al., 1987; Findlay et al., 1987; Creasy et al., 1993; Rogiers et al., 2001), monitoring of xylem and phloem mobile mineral transport (Creasy et al., 1993; Rogiers et al., 2000; Etchebarne et al., 2009), hydraulic conductance measurements (Tyerman et al., 2004), the measuring of berry turgor and hydraulic dynamics (Greer \& Rogiers, 2009) and xylem tracheary element analyses (Chatelet et al., 2008a), the mechanisms involved in the triggering and regulation of sugar and water import, as well as berry shrinkage at a specific ripeness level (particularly for a highly expressive cultivar like Shiraz), are not yet resolved and even still controversial. Most of the mechanisms, hypotheses and disputes are summarised in Fig. 1.

Essentially, the softening and deformability of fruit are due to the breakdown of cortex parenchyma cell walls, the latter which are composed mainly of polysaccharides, classified into pectin, cellulose and hemi-cellulose; significant depolymerisation occurs in grapes (Goulao \& Oliveira, 2008). The cell wall composition, dynamics and flexibility are extremely complex and still far from fully understood (Harholt et al., 2010). During grape ripening and the processing of the grapes (e.g. during skin contact and pressing), the berry cell walls are barriers to the diffusion and integration of many components essential to wine quality. Using transcriptomic tools to unravel berry softening processes, Glissant et al. (2008) found several structural and regulatory genes with expression profiles correlating to different ripening phases (middle-ripe, harvest-ripe and overripe) and which may be involved in cell wall modification. Co-expression, which suggests potential functional relationships between genes, and the concomitant action of isoforms, were also highlighted as playing significant roles. In a comprehensive study on the transcriptional network involved in the regulation of berry development, Deluc et al. (2007) profiled metabolites as well as mRNA expression in parallel. The results showed a magnitude of expressions at various stages of berry development, and

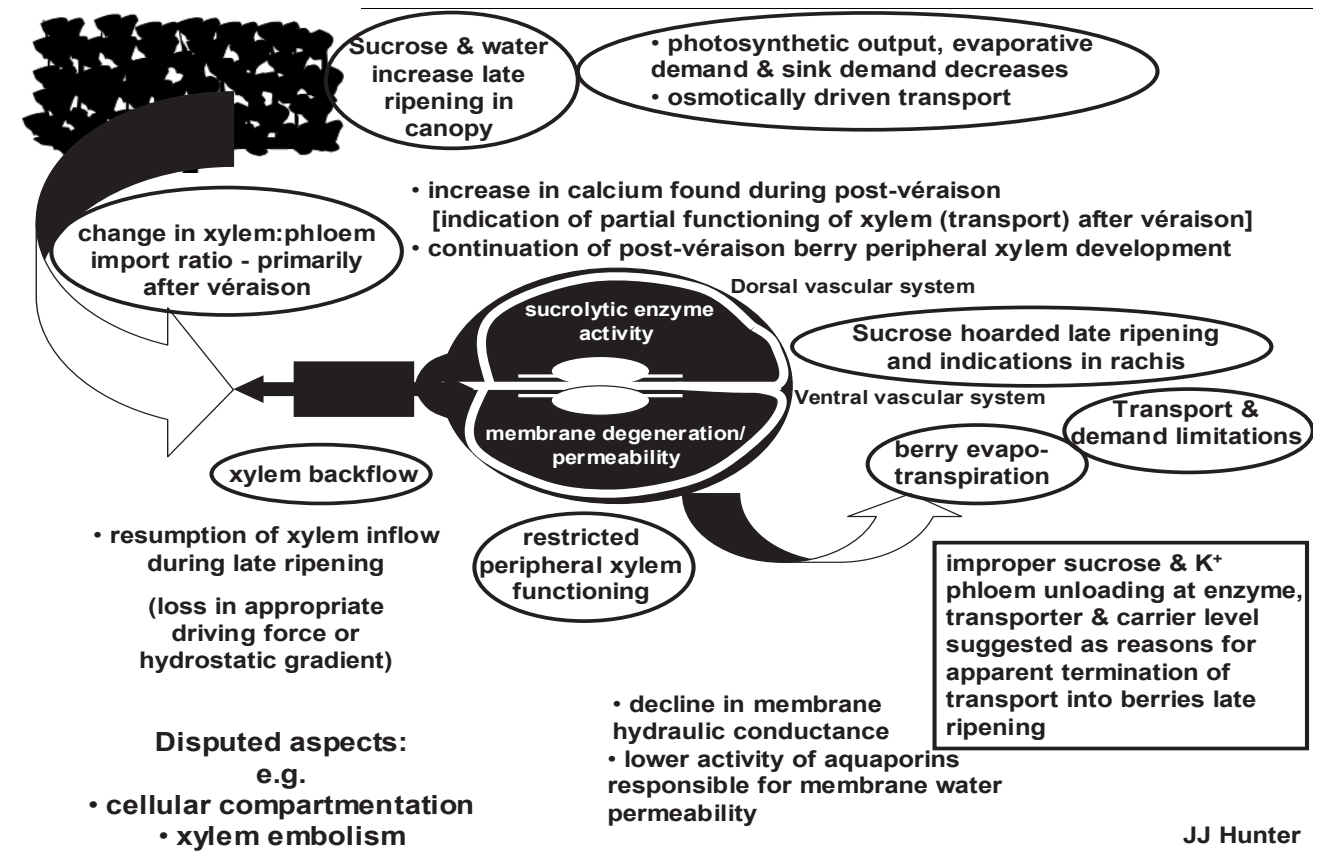

FIGURE 1

Regulatory processes between canopy and grapes during ripening (Hunter et al., 2010). 
clearly illustrated the dynamic nature of berry development, both metabolic and structural. Amongst the array of known (and obscure) transcripts related to practically all generally known physiological processes involved in the taste, flavour and protective behaviour of berries, multiple genes that may play key functional roles in cell wall structure, metabolism and softening were also identified. It clearly revealed the complex orchestration of metabolic, transport and control processes during the whole cycle of the developing berry. This study is complemented by another thorough study revealing the phenotypic plasticity of the grapevine under field conditions, showing clearly the environment-sensitivity of the expression and function of berry transcripts related to secondary metabolism (Dal Santo et al., 2013).

Indications are that sucrose and water transport to the grapes is regulated by a combination of photosynthetic activity, canopy and berry microclimate, osmotically driven transport, berry evapotranspiration, sucrolytic enzyme activity, membrane degeneration/permeability and a change in the ratio of xylem:phloem import, primarily after véraison (Lang \& Düring, 1991; Greenspan et al., 1994; Rebucci et al., 1997; Dreier et al., 1998, 2000; Greer \& Rogiers, 2009; Hunter et al., 2010). Many aspects, such as cellular compartmentation and xylem embolism, have been disputed (Chatelet et al., 2008a, 2008b; Fontes et al., 2011). According to Bondada et al. (2005), a loss in appropriate driving force or hydrostatic gradient may be involved in the (partial) loss of active xylem function after véraison. Furthermore, xylem backflow from the berries back to the parent vine during the late ripening stages has been proposed by many (Lang \& Thorpe, 1989; Schaller et al., 1992; Greenspan et al., 1996; McCarthy \& Coombe, 1999; Rogiers et al., 2006; Tilbrook $\&$ Tyerman, 2009). A resumption of xylem inflow during the late ripening stages has also been suggested, presumably to match the diminishing phloem flow (Schaller et al., 1992; Rogiers et al., 2006). Etchebarne et al. (2009) argued that the increase in calcium found during post-véraison under sufficient water supply may be taken as an indication that there is partial functioning of the xylem (transport) after véraison. A migration of calcium and potassium between berry compartments (from seeds/flesh to skins) also seems to occur during this time. This may have been a normal migration along with the osmotic gradients/balances created by the loss of water from the berry, and according to changes in cellular compartmentation integrity (Dreier et al., 1998, 2000). A continuation of post-véraison berry peripheral xylem development seems evident (Chatelet et al., 2008b), but whether this is involved (or at least significantly) in postvéraison water translocation into the berry (Greer \& Rogiers, 2009) is still debatable. Improper sucrose and potassium phloem unloading at enzyme, transporter and carrier level was suggested as a reason for the apparent termination of transport into the berries (Davies et al., 1999; Fillion et al., 1999; Pratelli et al., 2002). A decline in membrane hydraulic conductance seemed evident and significant during ripening (Tyerman et al., 2004), and lower activity of the aquaporins responsible for membrane water permeability and the control of water stress (Lovisolo et al., 2010) has been implicated (Delrot et al., 2001; Tyerman et al., 2002, 2004). It stands to reason that hormone activity, e.g. abscisic acid, may have a bigger role than mere association, particularly with regard to the triggering of berry ripening and, more often, its activity-steering involvement in osmotic balances and stress recognition and mediating the physiological state of the berry (Coombe, 1992; Hiratsuka et al., 2001; Yu et al., 2006; Wheeler et al., 2009).

Within the above perspective, the challenge at a practical and technological level lies in finding the relation between the cultivation-required aspects and complex physiological and developmental changes in canopy, conduits and berries, and the readiness of the grapes for harvesting and potential wine style/s that can be expected. A better understanding of the inter-relationships is required. To our knowledge, vegetative and reproductive growth that is subjected to various vine water status levels (with consideration of both volume of water and stage of application) has not been monitored systematically during ripening (specifically at different berry ripeness levels) under field conditions and in a challenging winter-rainfall region with occasional summer showers.

The focus of this study was on quantifying changes in vegetative and reproductive growth during the berry ripening period under different vine water status levels, introduced by means of irrigation at different stages and levels (volumes) during the growth season, as single or multiple applications. This study was followed by another study detailing the impact of vine water relations and grape ripeness levels on grape composition and wine quality/style.

\section{MATERIALS AND METHODS}

\section{Vineyard}

A seven-year-old Vitis vinifera L. cv. Shiraz (clone SH1A) vineyard, grafted onto Richter 99 (Vitis Berlandieri $\mathrm{x}$ Vitis rupestris) (clone RY2A), was used. The vineyard was located on the Experiment Farm of ARC InfruitecNietvoorbij in Stellenbosch, Western Cape, South Africa. The area is under the influence of a Mediterranean climate with winter rainfall (Fig. 2) (Hunter \& Bonnardot, 2011). The vines were spaced $2.75 \mathrm{~m} \times 1.5 \mathrm{~m}$ on a Glenrosa soil with western aspect $\left(26^{\circ}\right.$ slope $)$ and trained onto a sevenwire (cordon wire and three sets of movable wires, laterally spaced $15 \mathrm{~cm}$ ) lengthened Perold (VSP) trellising system with cordon wire at $60 \mathrm{~cm}$. Vines were pruned to two-bud spurs with a spur spacing of approximately $15 \mathrm{~cm}(\sim 10$ spurs/vine). Canopies were suckered (judicious removal of non-allocated infertile shoots on the cordon before the growth stage of approximately $30 \mathrm{~cm}$ primary shoot length), shoot positioned (shoots orientated to a vertical position by means of movable wires and then positioned by hand in line with their corresponding spurs - practice repeated as required with further canopy development) and tipped/ topped [tipping (removal of primary shoot tips) and topping (removal of primary shoot apical parts to $30 \mathrm{~cm}$ above the top wire) were done as required during the period berry set to pea size/véraison]. No leaf thinning was done in the canopies. Lateral shoots were tucked into the canopy and positioned vertically between the wires. Rye was sowed (at a density of $80 \mathrm{~kg} / \mathrm{ha}$ ) between the rows in autumn to serve as cover crop during the winter. The cover crop was killed in spring before bud break and left as mulch on the ground during the summer. 


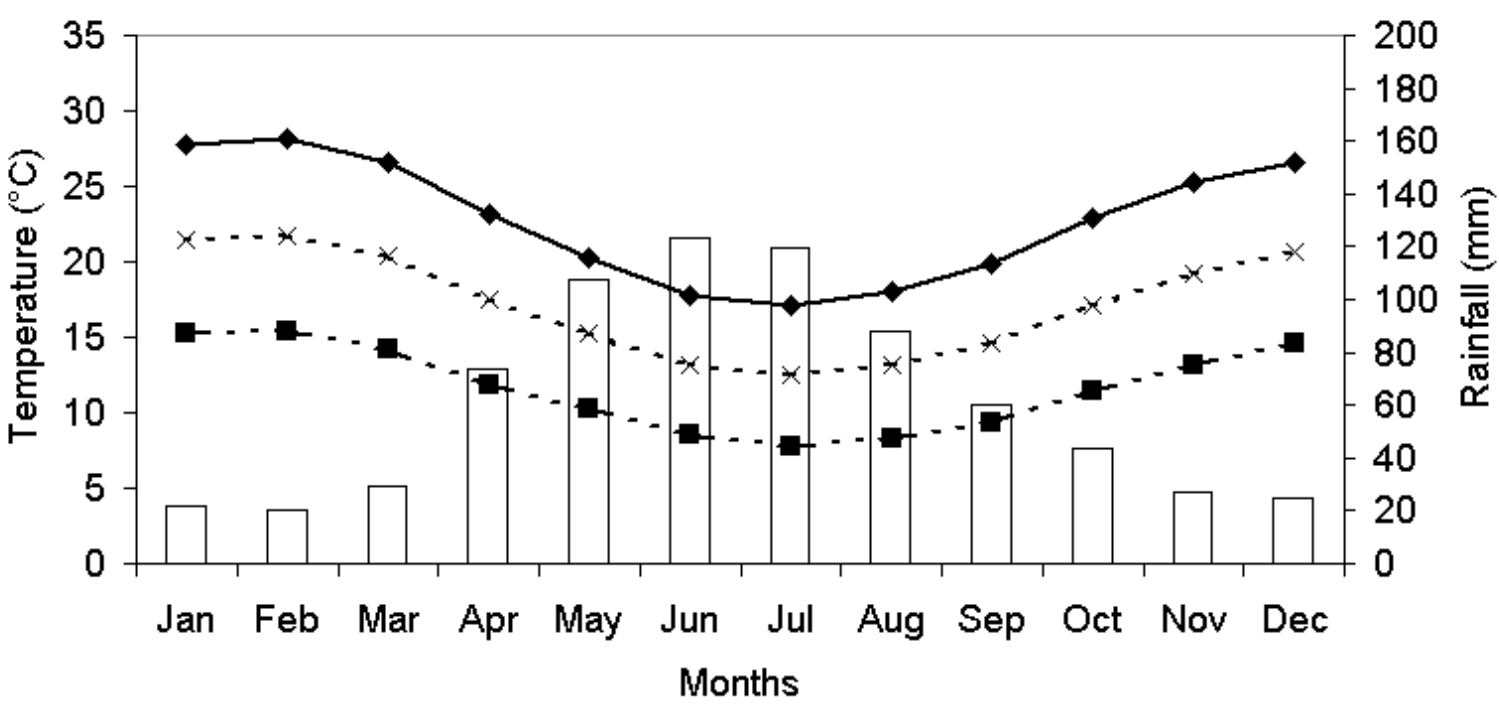

Rainfall $-\mathbf{\square}-$ MinT $--\rtimes-$ MeanT $\multimap-$ MaxT

FIGURE 2

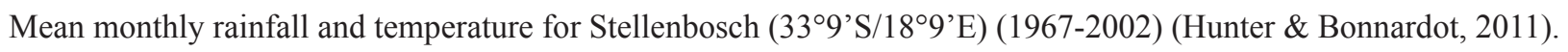

\section{Treatments and layout}

Fifteen treatments, comprising single and combined microsprinkler irrigations that differed in volume of water supplied and stage/s of application, were applied, as indicated in Table 1. Three water levels were implemented, i.e. no irrigation $(0 \% \mathrm{NI})$, and soil volume filled to $75 \%$ and $100 \%$ of field water capacity, respectively. Each irrigation treatment comprised either a single or different combinations of irrigations at different growth stages [berry set (BS), pea size berry (PS), véraison (V), and post-véraison (PV)]. Véraison represented at least $75 \%$ of grape colouring. Post-véraison refers to three weeks after $\mathrm{V}$. The treatments were completely randomised in two blocks (representing two replications), with a buffer row on each side of a treatment row and one buffer vine on each side of a treatment plot within the row. Thirty vines per replicate were used. Measurements were done at BS, PS, V, PV and at three ripeness levels. Soluble solid contents were used as indicator of ripeness level, i.e. $23^{\circ} \mathrm{B}, 25^{\circ} \mathrm{B}$ and $27^{\circ} \mathrm{B}$ (approximately 14 days between ripeness levels, corresponding to the beginning, middle and end of March). The treatments were applied in summer for four years in a row. The first two years were judged as calibrating years under field conditions. Mean values of the last two years of the experiment (2006/2007 and 2007/2008) are presented.

\section{Measurements and analyses}

Field water capacity (FWC) and bulk density of undisturbed soil cores (at $15 \mathrm{~cm}, 45 \mathrm{~cm}$ and $75 \mathrm{~cm}$ ) were determined by standard methods between the vineyard rows in six locations distributed at random in the experiment block. Both these soil parameters were used to calculate the volume of water needed to adjust the soil water content to either $75 \%$ or $100 \%$ of field water capacity at the different stages of irrigation application. Soil water ( $\mathrm{Sw}$ ) contents were determined gravimetrically, as well as by neutron probe at 10 to $30 \mathrm{~cm}, 30$ to $60 \mathrm{~cm}$ and 60 to
$90 \mathrm{~cm}$ depth respectively, at each measurement stage. Samples for soil particle size distribution and chemical characteristics (Soil Classification Working Group, 1991) were taken at the same depths.

Seven shoots (including bunches) per vine were sampled in order to determine total leaf area, primary and secondary leaf areas, number of primary leaves, number of secondary leaves and shoots, primary and secondary shoot lengths, bunch mass, and berry mass and volume. Berry skins were separated from the pulp, the fresh and dry mass was determined, and the water content was calculated. Leaf area was determined by means of a LICOR Model 3100 area meter.

Light intensity in the bunch zone of the canopy was measured during mid-morning by means of a LICOR Line Quantum Sensor (inserted at random into three separate canopies) and expressed as a percentage of ambient light level determined in the vine row at maximum canopy height at regular intervals during the measurement period. Photosynthetic activity (Pn) (together with transpiration) of three randomly selected exposed leaves on primary and secondary shoots in the basal and apical parts of the canopy was measured during mid-morning, using an open system ADC portable photosynthesis meter (The Analytical Development Co., Ltd., England), as specified in Hunter and Visser $(1988,1989)$. Leaf $\left(\Psi_{L}\right)$ and stem $\left(\Psi_{S}\right)$ (bagged for at least $30 \mathrm{~min}$. before measurement) water potential was determined on three randomly selected exposed mature leaves on primary and secondary shoots from early to mid-afternoon, using a pressure chamber as described by Scholander et al. (1965).

Soluble solids ( ${ }^{\circ}$ Balling) of the grape must per replicate were determined by standard methods after crushing of the grapes for winemaking purposes. Soluble solids per berry were calculated. Individual sugars in the leaves, rachis, whole berry, skin and pulp (obtained from two random sub-samples of the respective parts of the sampled shoots mentioned 
TABLE 1

Irrigation treatments applied to the Shiraz/Richter 99 vineyard.

\begin{tabular}{lcccc}
\hline Irrigation treatment & Berry set & Pea size & Véraison & Post-véraison \\
\hline 1. No irrigation $(\mathrm{NI})$ & $\mathrm{O}$ & $\mathrm{O}$ & $\mathrm{O}$ & $\mathrm{O}$ \\
2. $75 \%$ all stages $(75 \%$ all stages) & $3 / 4 \mathrm{X}$ & $3 / 4 \mathrm{X}$ & $3 / 4 \mathrm{X}$ & $3 / 4 \mathrm{X}$ \\
$3.100 \%$ all stages (all stages) & $\mathrm{X}$ & $\mathrm{X}$ & $\mathrm{X}$ & $\mathrm{X}$ \\
$4.75 \%$ pea size $(75 \% \mathrm{PS})$ & $\mathrm{O}$ & $3 / 4 \mathrm{X}$ & $\mathrm{O}$ & $\mathrm{O}$ \\
$5.100 \%$ pea size $(\mathrm{PS})$ & $\mathrm{O}$ & $\mathrm{X}$ & $\mathrm{O}$ & $\mathrm{O}$ \\
$6.75 \%$ véraison $(75 \% \mathrm{~V})$ & $\mathrm{O}$ & $\mathrm{O}$ & $3 / 4 \mathrm{X}$ & $\mathrm{O}$ \\
$7.100 \%$ véraison $(\mathrm{V})$ & $\mathrm{O}$ & $\mathrm{O}$ & $\mathrm{X}$ & $\mathrm{O}$ \\
$8.75 \%$ post-véraison $(75 \% \mathrm{PV})$ & $\mathrm{O}$ & $\mathrm{O}$ & $\mathrm{O}$ & $3 / 4 \mathrm{X}$ \\
$9.100 \%$ post-véraison $(\mathrm{PV})$ & $\mathrm{O}$ & $\mathrm{O}$ & $\mathrm{O}$ & $\mathrm{X}$ \\
$10.75 \%$ pea size \& véraison $(75 \% \mathrm{PS}+\mathrm{V})$ & $\mathrm{O}$ & $3 / 4 \mathrm{X}$ & $3 / 4 \mathrm{X}$ & $\mathrm{O}$ \\
$11.100 \%$ pea size \& véraison $(\mathrm{PS}+\mathrm{V})$ & $\mathrm{O}$ & $\mathrm{X}$ & $\mathrm{X}$ & $\mathrm{O}$ \\
$12.75 \%$ pea size \& post-véraison $(75 \% \mathrm{PS}+\mathrm{PV})$ & $\mathrm{O}$ & $3 / 4 \mathrm{X}$ & $\mathrm{O}$ & $3 / 4 \mathrm{X}$ \\
$13.100 \%$ pea size \& post-véraison $(\mathrm{PS}+\mathrm{PV})$ & $\mathrm{O}$ & $\mathrm{X}$ & $\mathrm{O}$ & $\mathrm{X}$ \\
$14.75 \%$ véraison \& post-véraison $(75 \% \mathrm{~V}+\mathrm{PV})$ & $\mathrm{O}$ & $\mathrm{O}$ & $3 / 4 \mathrm{X}$ & $3 / 4 \mathrm{X}$ \\
$15.100 \%$ véraison \& post-véraison $(\mathrm{V}+\mathrm{PV})$ & $\mathrm{O}$ & $\mathrm{O}$ & $\mathrm{X}$ & $\mathrm{X}$ \\
\hline
\end{tabular}

Véraison $=$ at least $75 \%$ colouring of grapes

Post-véraison $=$ three weeks after véraison

$\mathrm{O}=$ No irrigation, $3 / 4 \mathrm{X}=$ irrigation to $75 \%$ field water capacity, $\mathrm{X}=$ irrigation to $100 \%$ field water capacity

above) were extracted and analysed at all measurement stages by gas liquid chromatography (GLC) (after silylation), as described by Hunter and Ruffner (2001).

At any given stage, soil water determinations, physiological measurements and vegetative and reproductive growth sampling were completed during the course of two days, after which irrigation was applied as required for application of the different treatments.

\section{Statistical analyses}

The experiment design was a randomised block with two replications and thirty vines per replicate. Treatment design was a split-plot. The main plot was a factorial with treatments and stages as factors. According to Little and Hills (1978) a split-plot principle can be applied to experiments in which successive observations are made on the whole units over time (years). Analysis of variance was performed using SAS version 9.2 (SAS, 2012). The Shapiro-Wilk test was performed to test for non-normality (Shapiro \& Wilk, 1965). Student's t-Least Significant Difference was calculated at the $5 \%$ significance level to compare treatment means (Ott, 1998).

\section{RESULTS AND DISCUSSION}

\section{Soil structural, chemical and water conditions}

The Glenrosa soil used is classified as a predominantly sand-clay-loam soil (Table 2) and has an average FWC of approximately $17 \%$ (dry mass basis). The FWC of the different soil layers was similar. The soil compaction index (measured as bulk density) of the different soil layers slightly exceeded the critical value of $1.5 \mathrm{~g} / \mathrm{cm}^{3}$, beyond which root penetration is believed to decline (Richards, 1983). Resistance of the soil increased with increasing depth, whereas P, K and Ca decreased (Tables 3a \& 3b). Except for
Fe, contents of the micro-elements and carbon, as well as the texture of the soil, decreased with depth.

The Sw contents are given only at the different harvest times (rest of data not shown) (Fig. 3). Although general trends are recognisable, the gravimetric and neutron probe $\mathrm{Sw}$ results, for the purpose of calibration, showed an extremely poor relationship, and gravimetric measurements were therefore used to determine Sw contents and calculate irrigation volumes. This aspect has serious implications for producers relying solely on neutron probe results for irrigation scheduling; re-calibration of the measuring device from soil to soil and with soil depth in complex, layered soils (with relatively high stone content) is essential. Although the familiar trend of increasing Sw content with increasing soil depth was evident, it is interesting that similar treatment effects occurred in the different soil layers. The drainage, holding and withdrawal dynamics of water in the different soil layers were similar. With a few exceptions, the $\mathrm{Sw}$ content (on a dry mass basis) stayed above 50\% FWC. However, a decreasing trend was noticeable from the first to the third harvest stage, with the water loss between the first two stages being the most noticeable (Fig. 3), irrespective of rainfall just prior to the second harvest stage in both seasons (Figs 4a \& 4b). Despite the relatively regular rainfall during the active growth period and the ripening period (Figs 4a \& 4b), at all stages (control), and noticeably at PV, and at PV and earlier stages combined, treatments with $\mathrm{Sw}$ adjusted to $100 \%$ FWC showed elevated Sw contents in all soil layers and at the different harvest stages. The treatments therefore were successful in reaching deeper soil layers, despite the increase in clay content with depth and the soil compaction that may have affected soil porosity, particularly in the top soil layer (Table 2). It seems that the reduction in $\mathrm{Sw}$ stemmed mostly from a loss of supplemented water and 
TABLE 2

Physical properties of the soil.

\begin{tabular}{|c|c|c|c|c|c|c|c|c|c|c|}
\hline \multirow{2}{*}{$\begin{array}{l}\text { Depth } \\
(\mathrm{cm})\end{array}$} & \multirow{2}{*}{$\begin{array}{l}\text { Clay } \\
(\%)\end{array}$} & \multirow{2}{*}{$\begin{array}{l}\text { Silt } \\
(\%)\end{array}$} & \multirow{2}{*}{$\begin{array}{l}\text { Stone } \\
(\operatorname{vol} \%)\end{array}$} & \multicolumn{5}{|c|}{ Sand $(\%)$} & $\begin{array}{c}\text { Bulk density } \\
\left(\mathrm{g} / \mathrm{cm}^{3}\right)\end{array}$ & $\begin{array}{l}\text { Field water capacity } \\
\text { (dry mass basis) }(\%)\end{array}$ \\
\hline & & & & Fine & Medium & Coarse & Total & Classification* & \multicolumn{2}{|c|}{ Measured at $15,45 \& 75 \mathrm{~cm}$ depth } \\
\hline $0-30$ & 21.60 & 12.44 & 16.0 & 49.35 & 8.99 & 7.62 & 65.96 & Sa-Cl-Lm & 1.62 & 17.20 \\
\hline $30-60$ & 25.58 & 10.60 & 19.5 & 48.67 & 8.69 & 6.46 & 63.82 & Sa-Cl-Lm & 1.60 & 16.92 \\
\hline $60-90$ & 28.56 & 10.64 & 12.0 & 45.95 & 8.44 & 6.42 & 60.80 & Sa-Cl-Lm & 1.60 & 17.37 \\
\hline
\end{tabular}

*Sa-Cl-Lm $=$ Sand-clay-loam soil

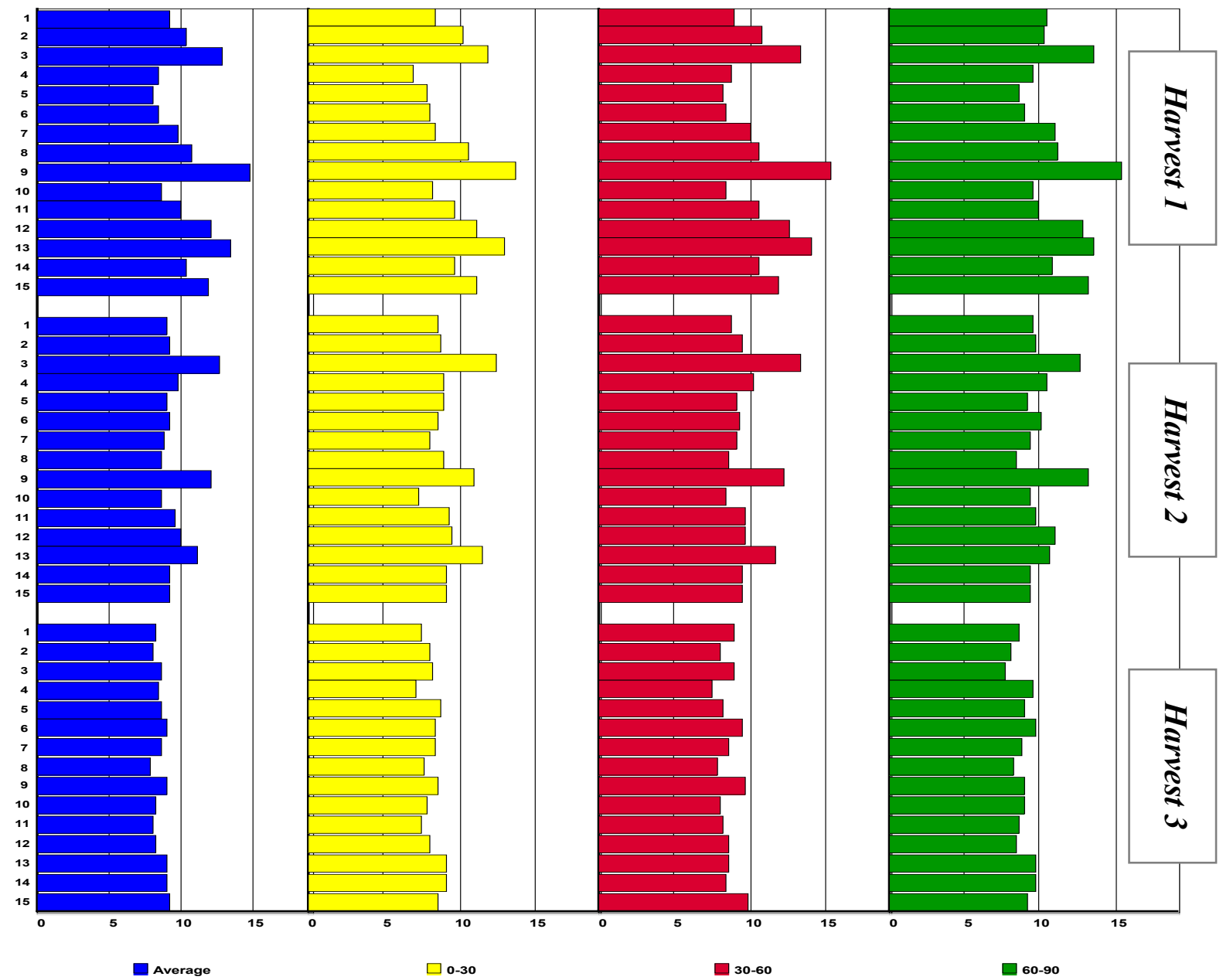

\section{Water content $(\%) /$ Soil layer}

FIGURE 3

Effect of level and stage of irrigation (number refers to the treatment as depicted in Table 1) on soil water content, measured in three layers and at three ripeness stages in the Shiraz/Richter 99 vineyard.

that a base Sw fraction stayed largely intact (Fig. 3). This is also evident from the relatively high $\mathrm{Sw}$ content of the non-irrigated treatment, particularly in the deepest soil layer and at the last harvest stage. The treatment effects on Sw content progressively diminished from the first to the third ripeness stage. It can be accepted that the water tension in the soil increased during the later stages of the growth season, but that the impact of plant transpiration on this would have been reduced because of less demanding climatic conditions, a senescing canopy, and reduced phloem water gradient between the berry and the parent plant during this time (Lang \& Thorpe, 1989; Schaller et al., 1992; Greenspan et al., 1996; McCarthy \& Coombe, 1999; Dreier et al., 2000; Hunter et al., 2004; Tyerman et al., 2004; Rogiers et al., 2006).

The soil clearly has a high water-holding capacity and 
TABLE 3a

Chemical analyses of the soil.

\begin{tabular}{|c|c|c|c|c|c|c|c|c|c|}
\hline \multirow[b]{2}{*}{ Depth (cm) } & \multirow[b]{2}{*}{$\mathrm{pH}(\mathrm{KCl})$} & \multirow[b]{2}{*}{ Resistance(Ohm) } & \multirow[b]{2}{*}{$\mathrm{H}(\mathrm{cmol} / \mathrm{kg})$} & $\mathrm{P}$ & & \multicolumn{4}{|c|}{ Exchangeable cations $[\mathrm{cmol}(+) / \mathrm{kg}]$} \\
\hline & & & & \multicolumn{2}{|c|}{$(\mathrm{mg} / \mathrm{kg})$} & $\mathrm{Na}$ & $\mathrm{K}$ & $\mathrm{Ca}$ & $\mathrm{Mg}$ \\
\hline $0-30$ & 5.8 & 2160 & 0.46 & 6.0 & 131.0 & 0.12 & 0.34 & 2.62 & 0.92 \\
\hline $30-60$ & 5.7 & 2520 & 0.39 & 3.0 & 62.0 & 0.10 & 0.16 & 2.25 & 0.54 \\
\hline $60-90$ & 5.5 & 2960 & 0.42 & 2.5 & 51.5 & 0.11 & 0.13 & 1.85 & 0.82 \\
\hline
\end{tabular}

TABLE $3 b$

Chemical analyses of the soil.

\begin{tabular}{|c|c|c|c|c|c|c|c|c|c|c|c|}
\hline \multirow[b]{2}{*}{ Depth $(\mathrm{cm})$} & $\mathrm{Cu}$ & $\mathrm{Zn}$ & $\mathrm{Mn}$ & B & $\mathrm{Fe}$ & $\mathrm{C}$ & $\mathrm{Na}$ & $\mathrm{K}$ & $\mathrm{Ca}$ & $\mathrm{Mg}$ & \multirow{2}{*}{$\begin{array}{c}\text { T-value } \\
\text { (cmol/kg) }\end{array}$} \\
\hline & \multicolumn{5}{|c|}{$(\mathrm{mg} / \mathrm{kg})$} & \multicolumn{5}{|c|}{$(\%)$} & \\
\hline $0-30$ & 1.17 & 2.25 & 19.00 & 0.15 & 3.11 & 0.94 & 2.55 & 4.44 & 59.06 & 20.72 & 4.44 \\
\hline $30-60$ & 0.97 & 0.60 & 9.90 & 0.08 & 4.44 & 0.41 & 2.91 & 3.44 & 65.43 & 15.67 & 3.44 \\
\hline $60-90$ & 0.70 & 0.30 & 6.45 & 0.07 & 4.55 & 0.17 & 3.31 & 3.32 & 56.24 & 23.22 & 3.32 \\
\hline
\end{tabular}

a buffer capacity against favourable evapotranspiration conditions, even with its western aspect and being subjected to long and relatively dry seasons with frequent occurrence of high temperatures (Figs $4 \mathrm{a} \& 4 \mathrm{~b}$ ), and having grapevines with canopies fully developed on the trellising system. Although a root study was not part of the investigation, it is unlikely that the composition of the root system (in terms of root thickness) and distribution in the different soil layers could have been similar. It may be assumed that the root system would have been grossly distributed in the top 0 to $80 \mathrm{~cm}$ layer and that fine root presence would have been higher in at least the top soil layers, mostly the 0 to $30 \mathrm{~cm}$ layer, similar to what has been found for different cultivars in different soils (Archer \& Strauss, 1985; Swanepoel \& Southey, 1989; Hunter et al., 1995; Hunter, 1998a, and references therein).

\section{Vine water relations}

The vine $\Psi$ data showed clear trends (Table 4). Both level of irrigation and stage of irrigation effects were evident at all stages. The water status of the vines, irrespective of treatment, generally followed Sw content patterns. In general, an increasing water deficit seemed evident from the BS stage until the PV stage. Although the Sw contents showed a decreasing trend from the first to the second harvest stage (Fig. 3), the water relations of the vines mostly appeared to increase during this time (Table 4), most likely as a result of the rainfall just before the second harvest stage (Figs. 4a \& 4b). The general impression is that vines were not overly stressed. A well-developed root system, promoted by efficient soil preparation, may have contributed to the plant water status (Hunter \& Myburgh, 2001; Myburgh, 2005); this was however not determined in this study. Nonetheless, the reasonably well-maintained plant water relations are in line with relatively high base $\mathrm{Sw}$ fractions of mostly more than $50 \%$ of FWC (Fig. 3). Primary and secondary $\Psi_{L}$ and the internal hydraulic conductivity in the trunk and shoot (as reflected by $\Psi_{\mathrm{S}}$ ) displayed similar patterns. The $\Psi$ of primary and secondary leaves was not very different. The $\Psi_{\mathrm{S}}$ was generally higher than $\Psi_{\mathrm{L}}$. This is found commonly (Choné et al., 2001; Di Lorenzo et al., 2005). It also indicates that $\Psi_{\mathrm{L}}$ over mid-day is more sensitive to environmental changes in e.g. light, temperature and wind. However, the drier the conditions, the less the difference seemed to be. This tendency was also noticed under extremely hot conditions during the course of the experiment (data not shown), indicating stomatal closure. Although differences in $\Psi_{S}$ between treatments were more noticeable, $\Psi_{\mathrm{L}}$ as well as $\Psi_{\mathrm{S}}$ indicated that, in line with their higher Sw contents (Fig. 3), fully irrigated control vines (75\% and 100\%) and single and combined PV irrigated vines (75\% and $100 \%)$ were largely irresponsive to the rainfall just before the second harvest stage (Table 4). All other treatments responded positively. From the second to the third ripeness level, a general reduction in vine $\Psi$ occurred.

Fully irrigated vines and vines irrigated at PV, and in combination with earlier stages, also clearly responded to more $(100 \%)$ or less $(75 \%)$ water. Continuously irrigated vines maintained reasonably high $\Psi$ during the season. The $\Psi_{\mathrm{S}}$ results showed that fully irrigated vines and vines irrigated to $100 \%$ at PS+V best maintained water relations until the last harvest stage, whereas the highest deficits at the last harvest stages occurred with combinations of $75 \%$ irrigation at PS+V and $75 \%$ irrigation at PS+PV. Interestingly, all V treatments that were combined with earlier (PS) water applications, as well as all PV treatments, whether single or in combination with any earlier (PS and V) treatment, responded noticeably to more or less water. It further seems that, despite a general tendency towards lower values, NI vines and vines irrigated only pre-véraison (at PS) developed an adaptive behaviour towards lower $\mathrm{Sw}$ contents and diurnal environmental stress; these vines reached their lowest water contents at the PV stage, after which they recuperated towards the second harvest stage and then largely stabilised after that. In contrast, the water relations of $\mathrm{V}$ - and $\mathrm{PV}$-irrigated vines seemed more unstable. According to Patakas \& Noitsakis 


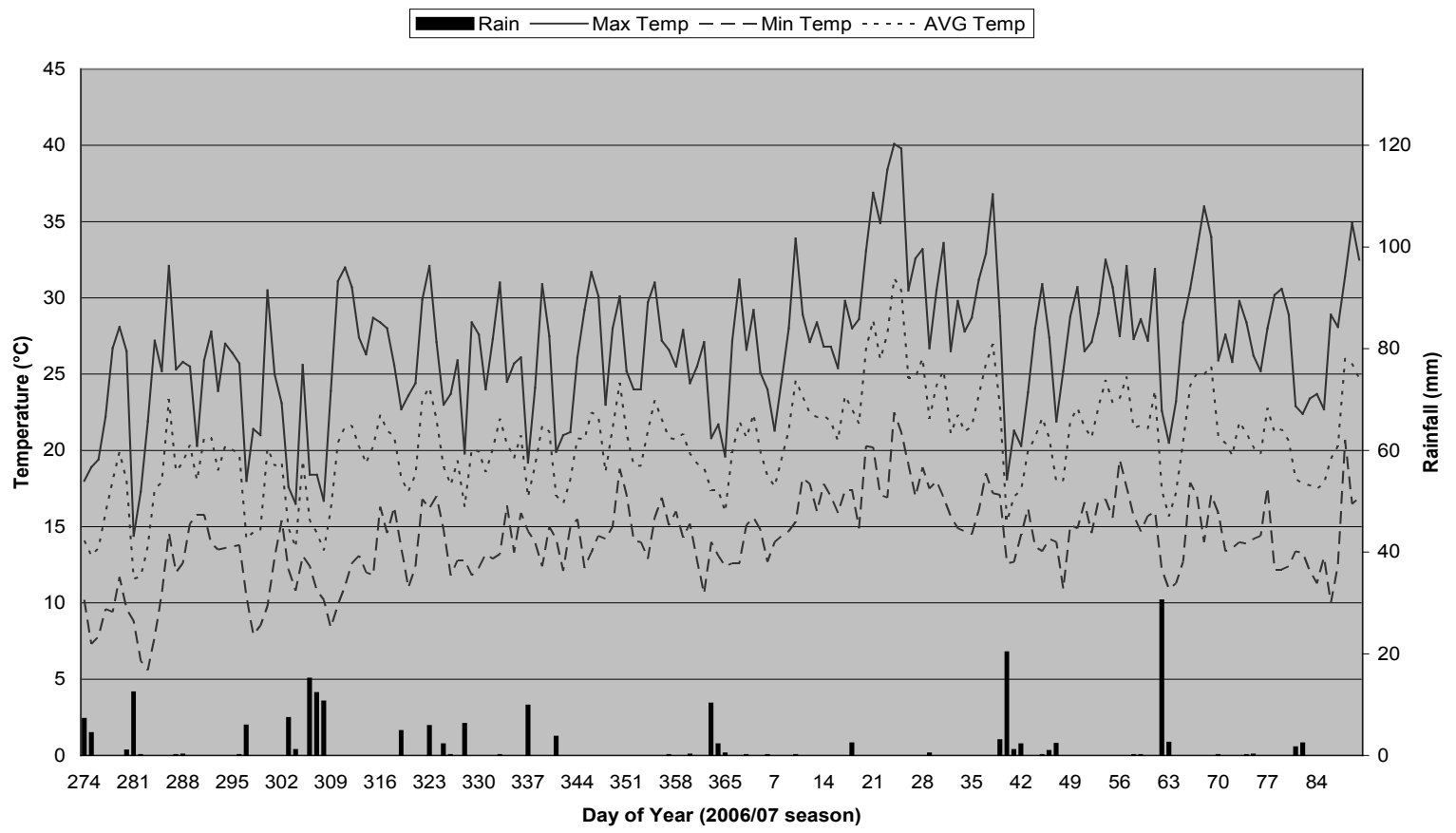

FIGURE 4a

Temperature and rainfall patterns for the 2006/2007 season at the experiment location.

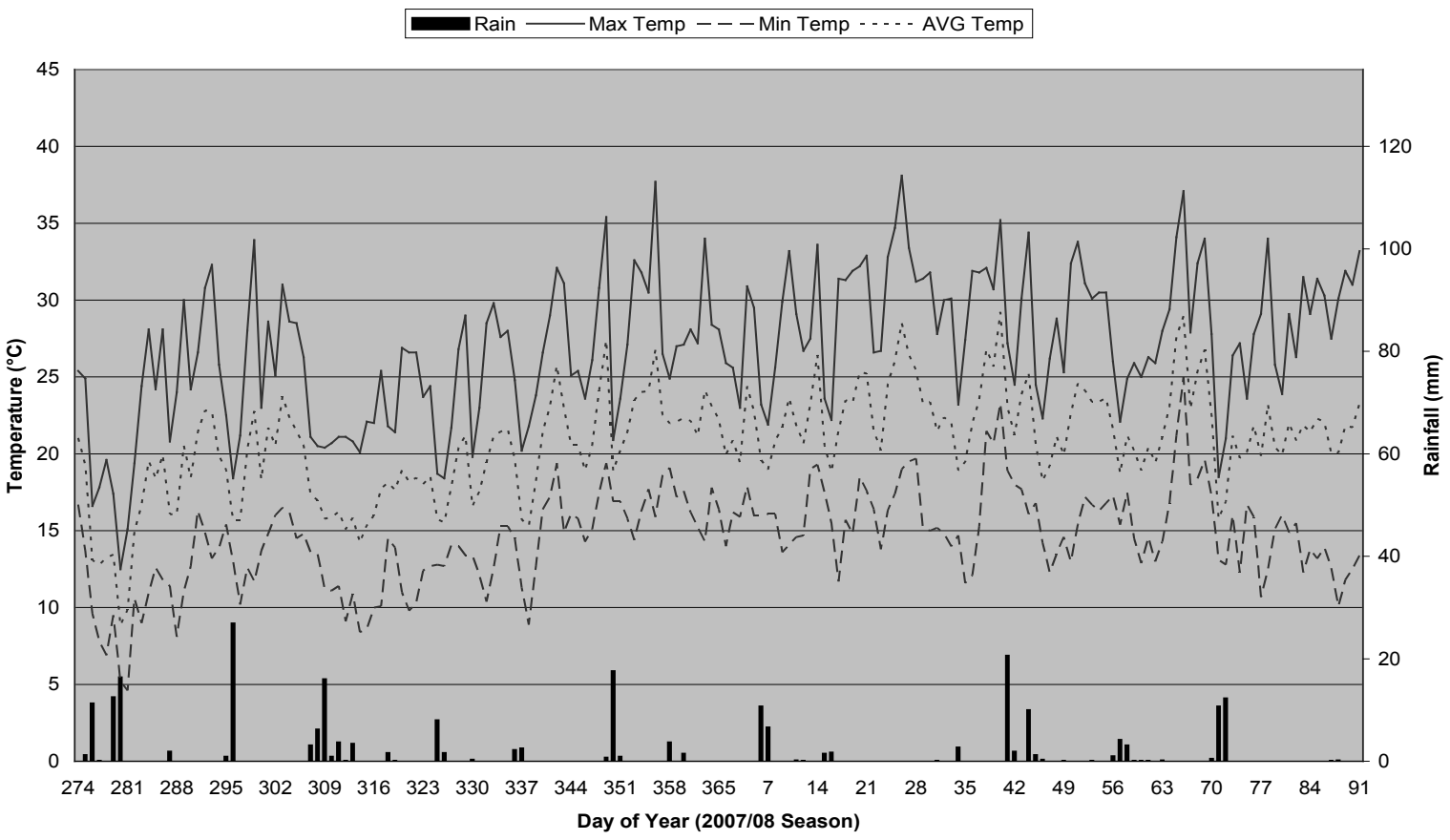

FIGURE $4 \mathrm{~b}$

Temperature and rainfall patterns for the 2007/2008 season at the experiment location.

(1999), an active osmotic adjustment may occur during the day under dry conditions. This would enable vines to maintain turgor. The most pronounced decrease in $\Psi$ from the first to the last harvest stage occurred for PV irrigations, both single and in combination with water applications at earlier stages. Although this behaviour coincided with the Sw loss trends shown in Fig. 3, the decrease in plant water was too excessive to judge as being solely resulting from a decrease in $\mathrm{Sw}$ when comparing this to the trends of the other treatments. In comparison to the other treatments, any PV-irrigated vine was expected to maintain relatively high $\Psi$ during the last weeks of the ripening period, but this seemed not to be the case.

\section{Photosynthetic activity}

Differences amongst treatments were not consistent and highlighting any would be speculative (Table 5). However, seasonal trends are evident. From after véraison until the 


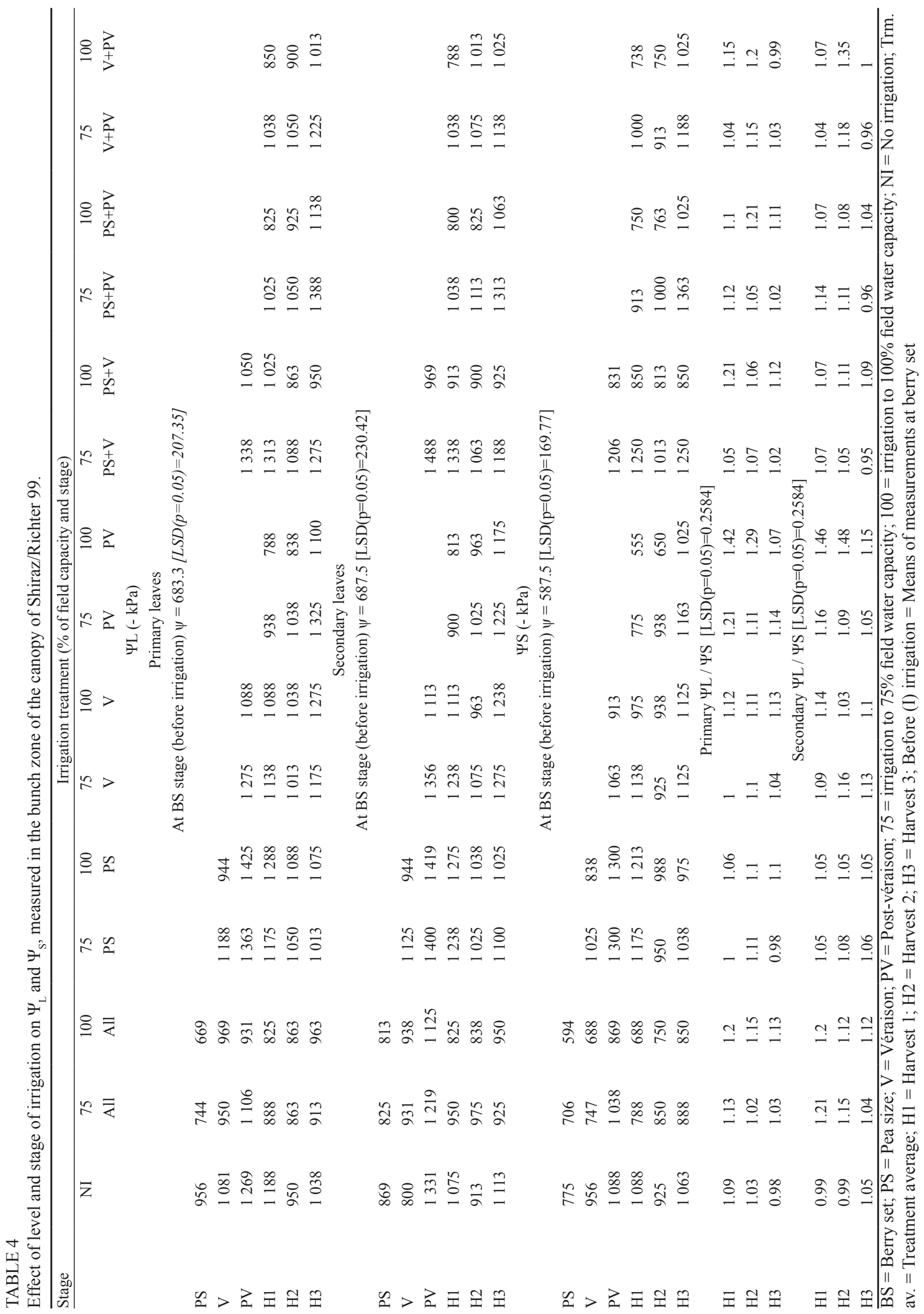


third harvest stage, apical primary leaves and secondary leaves generally displayed higher Pn than primary basal leaves. Apical leaves generally outperformed basal leaves on either primary or secondary shoots. Being younger, apical primary leaves and secondary leaves generally responded better to decreasing photosynthetic active radiation during ripening, and would be more involved in metabolic processes to satisfy sucrose and osmotic balance demands during this time (Hunter et al., 1994; Hunter \& Ruffner, 2001; Hunter et al., 2004). They would also have been less sensitive to abiotic influences compared to the primary leaves. According to Patakas et al. (1997), the capability for osmoregulation was almost the same in mature and immature leaves, but decreased with age. Immature leaves have more elastic cell walls, rendering them able to maintain positive cell turgor under lower leaf water conditions. Although not necessarily immature, the younger secondary leaves thus may have a better ability to buffer the impact of unfavourable environmental conditions, e.g. high temperatures, on grape development and ripening (Hunter, 2000; Hunter et al., 2004; Novello \& Hunter, 2004). In addition to water management (and appropriate fertilisation programmes), it is important that the initiation and development of secondary leaves are stimulated pre-véraison by judicious canopy management in order to maintain canopy capacity and increase the potential of the canopy to support the grapes when adverse environmental conditions are experienced during ripening (Hunter, 2000).

After the second harvest stage (and despite the rainfall just prior to that - Figs $4 \mathrm{a} \& 4 \mathrm{~b}$ ), a general drop in Pn occurred (Table 5). This may be indicative of senescence of the whole canopy, but also may be evidence that sucrose build-up in the leaves as a result of reduced demand from the rest of the vine, including the berries (Hunter et al., 1994, 2004). Noticeably, the vines were not highly stressed and non-irrigated vines maintained comparatively high $\mathrm{Pn}$. This may be a result of isohydric behaviour of the grapevine, which involves an active stomatal regulation of transpiration in order to prevent low $\Psi$-induced leaf damage (Schultz \& Matthews, 1988; Naor \& Wample, 1994; Escalona et al., 2002). The general decrease in photosynthetic water-use efficiency (indicated by the Pn:T ratio) from after véraison was reversed by the second harvest stage (Table 5); this corresponded with the increase in water relations during this time (Table 4) and is also indicative of a still active canopy. Given the relatively high Sw contents (Fig. 3), decreasing $\Psi$ occurring for irrigated vines during late grape ripening would probably be imposed mainly by a lack of continued high water absorption by the roots, as is particularly noticeable for vines that received irrigation during the ripening period. This may still have triggered so-called stress hormones, e.g. abscisic acid (Hunter, 1998b; Lovisolo et al., 2002; Patakas et al., 2005), and may have been favoured by a senescing canopy and prevailing cooler day and night temperatures, which would influence $\Psi$ gradients and source:sink relationships. High levels of abscisic acid in the leaves (Patakas et al., 2005) may trigger and increase the sensitivity of stomata to vapour pressure deficit (VPD) (Lovisolo et al., 2002). The general impression, however, was that vines had recuperated/stabilised during this time, maintaining water balances to support reserve-accumulating compartments, amongst others. This is supported by the slightly decreasing

TABLE 5

Effect of level and stage of irrigation on photosynthesis (Pn), transpiration (T) and photosynthetic water use efficiency (Pn:T) of leaves of Shiraz/Richter 99.

\begin{tabular}{|c|c|c|c|c|c|c|c|c|c|c|c|c|c|}
\hline \multirow[b]{4}{*}{ Stage } & \multirow{4}{*}{$\begin{array}{c}\text { Irrigation } \\
\text { treatment } \\
\text { (stage }+ \text { level) }\end{array}$} & \multicolumn{12}{|c|}{$\operatorname{Pn}\left(\mu \mathrm{mol} / \mathrm{m}^{2} / \mathrm{s}\right) / \mathrm{T}\left(\mathrm{mmol} / \mathrm{m}^{2} / \mathrm{s}\right) / \mathrm{Pn}: \mathrm{T}\left(\mathrm{X} 10^{-3}\right)$} \\
\hline & & \multicolumn{6}{|c|}{ Primary leaves } & \multicolumn{6}{|c|}{ Secondary leaves } \\
\hline & & \multicolumn{3}{|c|}{ Basal } & \multicolumn{3}{|c|}{ Apical } & \multicolumn{3}{|c|}{ Basal } & \multicolumn{3}{|c|}{ Apical } \\
\hline & & Pn & $\mathbf{T}$ & Pn:T & Pn & $\mathbf{T}$ & Pn:T & Pn & $\mathbf{T}$ & Pn:T & Pn & $\mathbf{T}$ & Pn:T \\
\hline \multirow[t]{3}{*}{ PS } & NI & 14.3 & 5.2 & 2.8 & 9.9 & 3.7 & 2.6 & 12.6 & 4.41 & 2.9 & 8.9 & 3.9 & 2.3 \\
\hline & 75All stages & 13.7 & 5.1 & 2.7 & 11.2 & 4.2 & 2.6 & 10.0 & 4.14 & 2.4 & 9.6 & 3.9 & 2.5 \\
\hline & 100All stages & 15.0 & 5.4 & 2.8 & 8.9 & 3.7 & 2.4 & 11.5 & 4.61 & 2.5 & 8.8 & 3.9 & 2.3 \\
\hline \multirow[t]{5}{*}{$\mathbf{V}$} & NI & 10.1 & 4.6 & 2.2 & 8.7 & 5.4 & 1.6 & 10.9 & 4.69 & 2.3 & 12.8 & 5.5 & 2.3 \\
\hline & 75All stages & 6.6 & 3.8 & 1.8 & 9.6 & 5.0 & 1.9 & 9.8 & 4.94 & 2.0 & 10.9 & 6.7 & 1.6 \\
\hline & 100All stages & 6.0 & 5.0 & 1.2 & 4.3 & 4.5 & 2.3 & 5.7 & 4.71 & 1.2 & 12.5 & 5.9 & 2.1 \\
\hline & 75PS & 7.6 & 3.6 & 2.1 & 4.2 & 2.4 & 1.7 & 6.6 & 3.22 & 2.0 & 7.7 & 3.6 & 2.2 \\
\hline & 100PS & 8.4 & 3.9 & 2.1 & 9.1 & 5.6 & 1.6 & 6.1 & 5.81 & 1.0 & 11.7 & 5.4 & 2.2 \\
\hline \multirow[t]{9}{*}{ PV } & NI & 7.0 & 3.3 & 2.1 & 10.9 & 4.6 & 2.4 & 7.3 & 3.89 & 1.9 & 8.2 & 4.1 & 2.0 \\
\hline & 75All stages & 4.9 & 3.9 & 1.3 & 11.7 & 6.0 & 1.9 & 9.0 & 4.99 & 1.8 & 12.0 & 5.5 & 2.2 \\
\hline & 100All stages & 9.6 & 5.8 & 1.7 & 12.0 & 6.1 & 2.0 & 9.8 & 5.51 & 1.8 & 12.8 & 6.4 & 2.0 \\
\hline & 75PS & 8.3 & 3.8 & 2.2 & 7.9 & 4.6 & 1.7 & 6.0 & 3.47 & 1.7 & 10.8 & 5.2 & 2.1 \\
\hline & 100PS & 4.3 & 2.8 & 1.5 & 9.1 & 4.5 & 2.0 & 6.2 & 3.75 & 1.7 & 6.9 & 4.4 & 1.6 \\
\hline & $75 \mathrm{~V}$ & 9.7 & 5.5 & 1.7 & 11.4 & 6.1 & 1.9 & 9.6 & 5.00 & 1.9 & 10.8 & 6.0 & 1.8 \\
\hline & $100 \mathrm{~V}$ & 4.8 & 5.1 & 0.9 & 10.3 & 5.6 & 1.8 & 5.2 & 5.33 & 1.0 & 10.9 & 6.2 & 1.8 \\
\hline & 75PS+V & 6.1 & 4.3 & 1.4 & 6.6 & 4.9 & 1.3 & 9.7 & 4.30 & 2.3 & 7.5 & 4.9 & 1.5 \\
\hline & $100 \mathrm{PS}+\mathrm{V}$ & 8.1 & 4.8 & 1.7 & 11.3 & 6.0 & 1.9 & 6.5 & 5.53 & 1.2 & 7.1 & 5.0 & 1.4 \\
\hline
\end{tabular}




\begin{tabular}{|c|c|c|c|c|c|c|c|c|c|c|c|c|c|}
\hline \multirow[b]{4}{*}{ Stage } & \multirow{4}{*}{$\begin{array}{c}\text { Irrigation } \\
\text { treatment } \\
\text { (stage + level) } \\
\end{array}$} & \multicolumn{12}{|c|}{$\mathrm{Pn}\left(\mu \mathrm{mol} / \mathrm{m}^{2} / \mathrm{s}\right) / \mathrm{T}\left(\mathrm{mmol} / \mathrm{m}^{2} / \mathrm{s}\right) / \mathrm{Pn}: \mathrm{T}\left(\mathrm{X} 10^{-3}\right)$} \\
\hline & & \multicolumn{6}{|c|}{ Primary leaves } & \multicolumn{6}{|c|}{ Secondary leaves } \\
\hline & & \multicolumn{3}{|c|}{ Basal } & \multicolumn{3}{|c|}{ Apical } & \multicolumn{3}{|c|}{ Basal } & \multicolumn{3}{|c|}{ Apical } \\
\hline & & Pn & $\mathbf{T}$ & Pn:T & Pn & $\mathbf{T}$ & Pn:T & Pn & $\mathbf{T}$ & Pn:T & Pn & $\mathbf{T}$ & Pn:T \\
\hline \multirow[t]{15}{*}{ H1 } & NI & 8.4 & 6.7 & 1.3 & 9.4 & 6.6 & 1.4 & 5.5 & 6.27 & 0.9 & 5.6 & 7.1 & 0.8 \\
\hline & 75All stages & 2.8 & 4.6 & 0.6 & 6.2 & 7.1 & 0.9 & 9.1 & 6.55 & 1.4 & 9.9 & 7.0 & 1.4 \\
\hline & 100All stages & 7.7 & 6.4 & 1.2 & 12.4 & 7.5 & 1.7 & 7.7 & 7.40 & 1.0 & 6.2 & 6.8 & 0.9 \\
\hline & 75PS & 3.6 & 4.3 & 0.8 & 8.7 & 5.2 & 1.7 & 9.0 & 5.40 & 1.7 & 10.6 & 5.6 & 1.9 \\
\hline & 100PS & 5.5 & 4.3 & 1.3 & 5.0 & 3.9 & 1.3 & 5.2 & 3.98 & 1.3 & 6.7 & 4.3 & 1.6 \\
\hline & $75 \mathrm{~V}$ & 4.0 & 4.3 & 0.9 & 8.6 & 5.0 & 1.7 & 7.5 & 4.81 & 1.6 & 8.9 & 5.9 & 1.5 \\
\hline & $100 \mathrm{~V}$ & 7.0 & 6.8 & 1.0 & 6.4 & 6.3 & 1.0 & 6.9 & 6.46 & 1.1 & 10.9 & 6.7 & 1.6 \\
\hline & $75 \mathrm{PV}$ & 6.3 & 6.3 & 1.0 & 9.3 & 6.4 & 1.5 & 10.2 & 6.58 & 1.5 & 9.4 & 6.5 & 1.4 \\
\hline & 100PV & 9.0 & 5.4 & 1.7 & 9.9 & 5.5 & 1.8 & 5.2 & 6.06 & 0.9 & 3.1 & 6.8 & 0.5 \\
\hline & 75PS+V & 2.9 & 3.2 & 0.9 & 6.3 & 4.4 & 1.4 & 4.4 & 3.33 & 1.3 & 5.5 & 4.0 & 1.4 \\
\hline & $100 P S+V$ & 9.2 & 6.2 & 1.5 & 9.2 & 6.7 & 1.4 & 8.3 & 5.81 & 1.4 & 10.0 & 6.0 & 1.7 \\
\hline & 75PS+PV & 6.6 & 5.4 & 1.2 & 7.5 & 6.2 & 1.2 & 2.7 & 6.32 & 0.4 & 4.6 & 6.5 & 0.7 \\
\hline & 100PS+PV & 5.9 & 5.6 & 1.1 & 9.4 & 7.4 & 1.3 & 8.7 & 6.42 & 1.4 & 10.9 & 6.7 & 1.6 \\
\hline & $75 V+P V$ & 9.1 & 6.3 & 1.5 & 10.9 & 6.4 & 1.7 & 12.0 & 7.11 & 1.7 & 12.3 & 6.9 & 1.8 \\
\hline & $100 V+P V$ & 9.5 & 6.4 & 1.5 & 11.7 & 7.0 & 1.7 & 8.0 & 6.27 & 1.3 & 9.4 & 6.6 & 1.4 \\
\hline \multirow[t]{15}{*}{ H2 } & NI & 8.5 & 4.8 & 1.8 & 9.5 & 5.4 & 1.7 & 9.7 & 5.37 & 1.8 & 11.9 & 5.7 & 2.1 \\
\hline & 75All stages & 6.8 & 4.8 & 1.4 & 7.1 & 4.0 & 1.8 & 8.1 & 4.05 & 2.0 & 12.6 & 6.0 & 2.1 \\
\hline & 100All stages & 7.3 & 4.8 & 1.5 & 9.8 & 5.8 & 1.7 & 12.6 & 5.87 & 2.1 & 10.4 & 6.0 & 1.7 \\
\hline & 75PS & 4.1 & 2.6 & 1.6 & 7.1 & 4.4 & 1.6 & 7.6 & 3.81 & 2.0 & 8.4 & 4.0 & 2.1 \\
\hline & 100PS & 4.9 & 3.0 & 1.6 & 8.2 & 4.3 & 1.9 & 3.6 & 2.85 & 1.3 & 6.9 & 3.8 & 1.8 \\
\hline & $75 \mathrm{~V}$ & 3.6 & 2.4 & 1.5 & 8.0 & 3.7 & 2.2 & 10.6 & 4.85 & 2.2 & 10.1 & 4.3 & 2.3 \\
\hline & $100 \mathrm{~V}$ & 4.5 & 3.9 & 1.2 & 10.8 & 5.0 & 2.2 & 8.0 & 4.44 & 1.8 & 5.6 & 5.4 & 1.0 \\
\hline & $75 \mathrm{PV}$ & 9.1 & 5.1 & 1.8 & 7.3 & 4.8 & 1.5 & 11.5 & 5.32 & 2.2 & 11.4 & 5.1 & 2.2 \\
\hline & 100PV & 7.7 & 4.2 & 1.8 & 9.2 & 4.6 & 2.0 & 8.9 & 4.24 & 2.1 & 13.5 & 5.0 & 2.7 \\
\hline & 75PS+V & 4.5 & 2.8 & 1.6 & 5.3 & 3.1 & 1.7 & 4.4 & 2.85 & 1.5 & 8.0 & 4.5 & 1.8 \\
\hline & $100 \mathrm{PS}+\mathrm{V}$ & 6.4 & 4.6 & 1.4 & 6.5 & 4.3 & 1.5 & 8.5 & 4.60 & 1.8 & 13.8 & 6.2 & 2.2 \\
\hline & 75PS+PV & 5.6 & 3.4 & 1.6 & 10.7 & 4.8 & 2.2 & 12.7 & 5.57 & 2.3 & 12.7 & 5.7 & 2.2 \\
\hline & 100PS+PV & 5.6 & 3.7 & 1.5 & 10.3 & 5.3 & 1.9 & 11.1 & 5.29 & 2.1 & 9.7 & 5.5 & 1.8 \\
\hline & $75 \mathrm{~V}+\mathrm{PV}$ & 7.2 & 3.9 & 1.8 & 8.7 & 4.6 & 1.9 & 11.5 & 5.28 & 2.2 & 10.7 & 5.1 & 2.1 \\
\hline & $100 V+P V$ & 5.8 & 3.8 & 1.5 & 10.9 & 5.2 & 2.1 & 8.3 & 4.62 & 1.8 & 12.1 & 5.7 & 2.1 \\
\hline \multirow[t]{16}{*}{ H3 } & NI & 4.6 & 3.0 & 1.5 & 5.3 & 3.1 & 1.7 & 4.8 & 3.20 & 1.5 & 7.2 & 4.2 & 1.7 \\
\hline & 75All stages & 4.7 & 4.0 & 1.2 & 7.6 & 5.0 & 1.5 & 2.7 & 2.93 & 0.9 & 4.4 & 4.5 & 1.0 \\
\hline & 100All stages & 5.4 & 4.0 & 1.3 & 6.4 & 4.5 & 1.4 & 4.1 & 3.31 & 1.2 & 8.8 & 5.1 & 1.7 \\
\hline & 75PS & 3.7 & 2.5 & 1.5 & 5.9 & 3.4 & 1.7 & 4.6 & 2.65 & 1.7 & 3.6 & 3.5 & 1.0 \\
\hline & 100PS & 3.7 & 2.6 & 1.4 & 6.4 & 4.1 & 1.5 & 2.5 & 2.09 & 1.2 & 6.0 & 3.5 & 1.7 \\
\hline & $75 \mathrm{~V}$ & 5.6 & 3.2 & 1.7 & 6.1 & 3.6 & 1.7 & 3.3 & 2.12 & 1.6 & 7.2 & 3.6 & 2.0 \\
\hline & $100 \mathrm{~V}$ & 3.7 & 3.1 & 1.2 & 5.3 & 3.3 & 1.6 & 5.6 & 3.40 & 1.7 & 6.1 & 3.5 & 1.8 \\
\hline & $75 \mathrm{PV}$ & 2.5 & 2.4 & 1.1 & 7.6 & 4.1 & 1.8 & 2.8 & 2.02 & 1.4 & 6.5 & 4.0 & 1.6 \\
\hline & 100PV & 8.0 & 3.8 & 2.1 & 10.7 & 4.4 & 2.4 & 7.9 & 3.76 & 2.1 & 9.8 & 4.3 & 2.3 \\
\hline & $75 P S+V$ & 2.8 & 1.7 & 1.6 & 6.0 & 4.3 & 1.4 & 4.4 & 2.53 & 1.7 & 3.5 & 2.2 & 1.6 \\
\hline & $100 P S+V$ & 2.3 & 2.6 & 0.9 & 6.3 & 4.2 & 1.5 & 5.2 & 3.77 & 1.4 & 5.4 & 4.0 & 1.4 \\
\hline & 75PS+PV & 3.4 & 2.0 & 1.7 & 8.9 & 3.8 & 2.3 & 5.0 & 2.44 & 2.0 & 8.1 & 3.6 & 2.2 \\
\hline & $100 P S+P V$ & 3.8 & 3.0 & 1.3 & 7.1 & 4.1 & 1.7 & 6.6 & 4.27 & 1.5 & 7.8 & 4.8 & 1.6 \\
\hline & $75 V+P V$ & 2.4 & 1.8 & 1.3 & 3.7 & 3.4 & 1.1 & 5.5 & 3.19 & 1.7 & 6.7 & 3.4 & 2.0 \\
\hline & $100 V+P V$ & 4.5 & 3.6 & 1.2 & 6.8 & 4.6 & 1.5 & 6.2 & 4.27 & 1.5 & 6.1 & 4.7 & 1.3 \\
\hline & $L S D(p=0.05)$ & 4.93 & 1.60 & 0.95 & 6.35 & 1.52 & 1.04 & 4.90 & 1.70 & 0.81 & 5.39 & 1.23 & 0.91 \\
\hline
\end{tabular}

$\mathrm{BS}=$ Berry set; $\mathrm{PS}=$ Pea size; $\mathrm{V}=$ Véraison; $\mathrm{PV}=$ Post-véraison; $75=$ irrigated to $75 \%$ field water capacity; $100=$ irrigated to $100 \%$ field water capacity; NI = No irrigation; $\mathrm{H} 1=$ Harvest $1 ; \mathrm{H} 2=$ Harvest $2 ; \mathrm{H} 3=$ Harvest 3 
or stable " $\Psi_{\mathrm{L}}$ (primary \& secondary)": " $\Psi_{\mathrm{S}}$ " ratio from the first to the third harvest (Table 4).

\section{Vegetative growth}

Since the vines were topped, vigour would have been channelled mainly into secondary shoot growth. A natural decrease in primary and secondary leaf area occurred during berry ripening from at least the PV stage (Fig. 5, Tables 6a \& 6b) [see also Hunter \& Visser (1990) and Hunter et al. (2004)]. Although the later timing of irrigation treatments resulted in generally lower secondary leaf area, development at large showed varying responses to the volume of irrigation. Even with growth stimulation it would have been unlikely that primary or secondary leaves initiated in the late season would have reached sucrose export status and still significantly contributed to the grapes (Hunter \& Visser, 1988). On the other hand, re-growth after late-season irrigation may also be an indication of a still-active canopy, which may extend the harvesting window by continued translocation/contribution to grapes by existing exporting leaves. Sustaining early season-initiated secondary leaf area may not only increase photosynthetic capacity and support grape development, but also contribute to reserve accumulation after harvest (Hunter et al., 1994; Hunter, 2000; Vasconcelos \& Castagnoli, 2000). Non-irrigated vines maintained surprisingly high leaf area (Fig. 5), especially secondary leaf area, most probably because of the relatively high base Sw content (Fig. 3). This led to what were generally the lowest primary:secondary leaf area ratios. Pre-véraison irrigation seemed to result in the lowest ratios at the three harvest stages, which may be because of early stimulation of secondary leaf area development during a period in which tipping/topping was also done (Hunter, 2000).

\section{Reproductive growth}

Berries reached their highest mass approximately three weeks after véraison (PV) (Table 7). This is in agreement with earlier findings (Hunter et al., 2004). High base soil water under the conditions of the study may largely have prevented the surfacing of treatment as well as classic waterdeficit berry-size reduction effects (Williams \& Matthews, 1990; McCarthy, 1999; Ojeda et al., 2002; Roby \& Matthews, 2004; Myburgh, 2005). Bunch mass and volume started to decrease from PV already, whereas the rachis generally reached its highest mass only at the first harvest stage, after which it decreased (Fig. 6). Bunch, berry and rachis mass and volume continued to decrease during all ripening stages. The appearance of the rachis may not be an indication of berry condition (Hunter et al., 2004). The results seemed to indicate independent development and/or senescence for the berry and rachis, particularly during late ripening. The Sw contents (Fig. 3), $\Psi_{\mathrm{L}}$ and $\Psi_{\mathrm{S}}$ (Table 4), Pn (Table 5) and bunch and berry mass (Table 7) seemed concerted during the last ripening stages. Sucrose concentrations in the leaves reached peak values between PV and the first harvest stage, after which a general decline occurred (Fig. 7), in line with a senescing canopy (Fig. 5, Tables 6a \& 6b). It previously was found that sucrose built up in the primary and secondary leaves during late ripening (Hunter et al., 1994, 2004). This was also evident in this study (Fig. 7), particularly in the secondary leaves, and coincided with a general decrease in $\Psi$ (Table 4). This build-up of sucrose in the leaves, i.e. an over-supply of sucrose (be it because of concentration and/or a decrease in demand and/or phloem loading and/or phloem transport), may also nullify potential negative effects that the re-growth of secondary shoots or even tertiary shoot initiation after late-season irrigation may have on grape ripening. Parallel to that in the leaves, sucrose concentrations

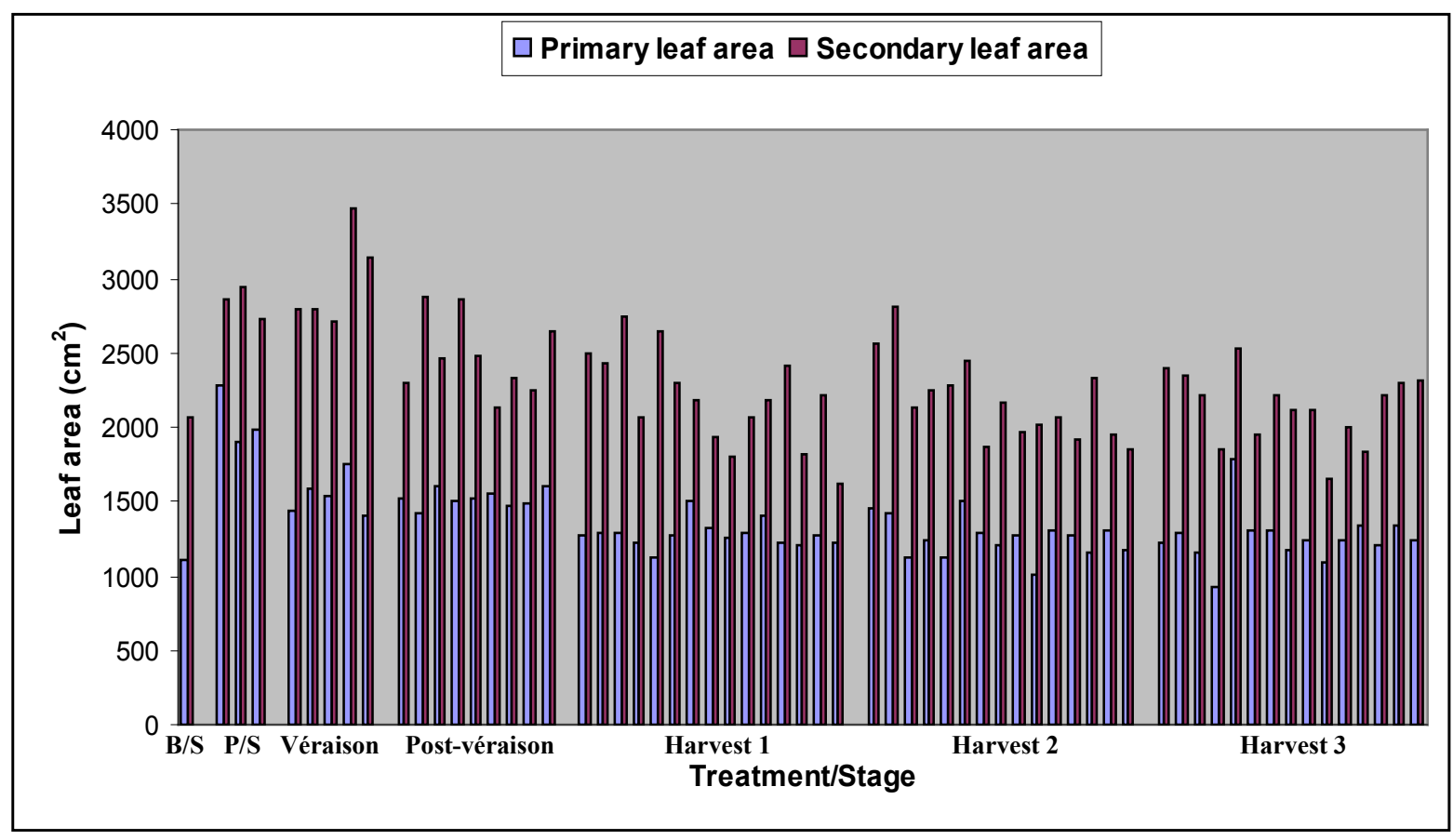

FIGURE 5

Trends in the evolution of vegetative growth of Shiraz/Richter 99 over stages. 
in the berry skin also seemed to peak between PV and the first harvest stage (Fig. 8). In contrast, the lowest sucrose concentrations in the pulp seemed to occur around the first harvest stage, after which it increased and then remained stable. This increase coincided with the lowest concentrations in the rachis, which then increased again, almost as if a resumption of transport from the rachis to the pulp occurred momentarily with the rainfall just before the second harvest stage. Sucrose concentrations in the skin and pulp therefore followed similar patterns up to PV, after which it increased in the skin and decreased in the pulp up to the second harvest stage; after this, a stable trend was evident in the pulp, but a decreasing trend was seen in the skin. Given the relatively low $\Psi$ in the canopy, the build-up of sucrose in the leaves, a more stable rachis mass, a reduction in berry size and the decreasing sucrose trend in the skin during this time, it is possible that the increase in sucrose in the rachis (Fig. 8) may indicate a point where phloem unloading into the berry is affected by $\Psi$ gradients, as well as by metabolic activity in the berries. The increase in sucrose content of the rachis suggests that transport to berries became restricted during this time, despite a generally and readily favourable sucrose gradient from the rachis to the berry, and a decreasing osmotic potential in the berry. This seems to indicate that rachis and berry behaviour is not concerted during ripening, with the rachis displaying more typical vegetative tissue

TABLE $6 \mathrm{a}$

Effect of level and stage of irrigation on vegetative growth (primary shoots) of Shiraz/Richter 99.

\begin{tabular}{|c|c|c|c|c|c|c|c|c|c|}
\hline \multirow[b]{2}{*}{ Stage } & \multirow{2}{*}{$\begin{array}{l}\text { Irrigation } \\
\text { treatment } \\
\text { (stage }+ \text { level) }\end{array}$} & \multicolumn{2}{|c|}{ Leaves/shoot } & \multicolumn{2}{|c|}{ Leaf mass } & \multicolumn{2}{|c|}{ Leaf area/shoot } & \multicolumn{2}{|c|}{ Shoot length } \\
\hline & & Number & Trm. av. & (g) & Trm. av. & $\left(\mathrm{cm}^{2}\right)$ & Trm. av. & $(\mathrm{cm})$ & Trm. av. \\
\hline BS & $\begin{array}{l}\text { Before } \\
\text { irrigation }\end{array}$ & 10.3 & 10.3 & 2.8 & 2.8 & 1112.0 & 1112.0 & 90.1 & 90.1 \\
\hline \multirow[t]{3}{*}{ PS } & NI & 12.6 & 12.6 & 2.9 & 2.9 & 2281.8 & 2281.8 & 103.0 & 103.0 \\
\hline & 75All stages & 13.1 & & 2.9 & & 1907.8 & & 107.3 & \\
\hline & 100All stages & 13.4 & 13.3 & 2.5 & 2.7 & 1978.6 & 1943.2 & 101.3 & 104.3 \\
\hline \multirow[t]{5}{*}{$\mathbf{V}$} & NI & 12.0 & 12.0 & 2.8 & & 1439.2 & 1439.2 & 90.8 & 90.8 \\
\hline & 75All stages & 13.8 & & 2.6 & & 1579.8 & & 116.9 & \\
\hline & 100All stages & 15.5 & 14.7 & 2.3 & 2.4 & 1538.4 & 1559.1 & 101.1 & 109.0 \\
\hline & 75PS & 14.7 & & 2.8 & & 1752.3 & & 112.9 & \\
\hline & 100PS & 12.7 & 13.7 & 2.7 & 2.7 & 1400.6 & 1576.5 & 108.0 & 110.4 \\
\hline \multirow[t]{9}{*}{ PV } & NI & 13.2 & 13.2 & 2.6 & 2.6 & 1519.5 & 1519.5 & 112.6 & 112.6 \\
\hline & 75All stages & 13.4 & & 2.5 & & 1416.4 & & 109.5 & \\
\hline & 100All stages & 16.3 & 14.9 & 2.3 & 2.4 & 1606.6 & 1511.5 & 120.4 & 115.0 \\
\hline & 75PS & 15.3 & & 2.2 & & 1501.8 & & 116.4 & \\
\hline & 100PS & 13.4 & 14.4 & 2.7 & 2.4 & 1519.6 & 1510.7 & 109.2 & 112.8 \\
\hline & $75 \mathrm{~V}$ & 15.7 & & 2.3 & & 1554.0 & & 106.2 & \\
\hline & $100 \mathrm{~V}$ & 13.5 & 14.6 & 2.6 & 2.4 & 1475.3 & 1514.7 & 103.8 & 105.0 \\
\hline & $75 \mathrm{PS}+\mathrm{V}$ & 14.6 & & 2.3 & & 1488.3 & & 105.9 & \\
\hline & $100 P S+V$ & 15.6 & 15.1 & 2.6 & 2.5 & 1611.5 & 1549.9 & 110.2 & 108.0 \\
\hline \multirow[t]{15}{*}{ H1 } & NI & 9.5 & 9.5 & 3.3 & 3.3 & 1266.8 & 1266.8 & 103.0 & 103.0 \\
\hline & 75All stages & 11.0 & & 2.8 & & 1296.3 & & 110.6 & \\
\hline & 100All stages & 13.5 & 12.3 & 2.3 & 2.6 & 1292.2 & 1294.2 & 105.0 & 107.8 \\
\hline & 75PS & 12.0 & & 2.2 & & 1221.6 & & 109.2 & \\
\hline & 100PS & 10.1 & 11.1 & 2.6 & 2.4 & 1117.7 & 1169.7 & 105.5 & 107.3 \\
\hline & $75 \mathrm{~V}$ & 9.6 & & 3.2 & & 1273.0 & & 101.6 & \\
\hline & $100 \mathrm{~V}$ & 12.0 & 10.8 & 2.9 & 3.1 & 1508.3 & 1390.7 & 104.6 & 103.1 \\
\hline & 75PV & 11.5 & & 2.6 & & 1317.0 & & 110.0 & \\
\hline & 100PV & 11.6 & 11.6 & 2.3 & 2.5 & 1263.3 & 1290.2 & 100.2 & 105.1 \\
\hline & $75 \mathrm{PS}+\mathrm{V}$ & 10.9 & & 2.8 & & 1285.4 & & 106.1 & \\
\hline & $100 P S+V$ & 12.9 & 11.9 & 2.7 & 2.8 & 1403.7 & 1344.5 & 108.8 & 107.4 \\
\hline & 75PS+PV & 9.5 & & 3.1 & & 1228.5 & & 102.3 & \\
\hline & $100 P S+P V$ & 9.9 & 9.7 & 3.0 & 3.0 & 1202.5 & 1215.5 & 96.1 & 99.2 \\
\hline & $75 V+P V$ & 9.1 & & 3.4 & & 1264.5 & & 97.8 & \\
\hline & $100 V+P V$ & 11.6 & 10.4 & 2.6 & 3.0 & 1230.5 & 1247.5 & 93.3 & 95.6 \\
\hline
\end{tabular}


TABLE 6a (CONTINUED)

\begin{tabular}{|c|c|c|c|c|c|c|c|c|c|}
\hline \multirow[b]{2}{*}{ Stage } & \multirow{2}{*}{$\begin{array}{l}\text { Irrigation } \\
\text { treatment } \\
\text { (stage + level) }\end{array}$} & \multicolumn{2}{|c|}{ Leaves/shoot } & \multicolumn{2}{|c|}{ Leaf mass } & \multicolumn{2}{|c|}{ Leaf area/shoot } & \multicolumn{2}{|c|}{ Shoot length } \\
\hline & & Number & Trm. av. & (g) & Trm. av. & $\left(\mathrm{cm}^{2}\right)$ & Trm. av. & $(\mathrm{cm})$ & Trm. av. \\
\hline \multirow[t]{15}{*}{ H2 } & NI & 12.7 & 12.7 & 2.5 & 2.5 & 1452.2 & 1452.2 & 112.1 & 112.1 \\
\hline & 75All stages & 12.8 & & 2.6 & & 1420.2 & & 110.0 & \\
\hline & 100All stages & 11.5 & 12.2 & 2.3 & 2.5 & 1119.5 & 1269.9 & 98.7 & 104.3 \\
\hline & 75PS & 13.2 & & 2.3 & & 1245.3 & & 107.6 & \\
\hline & 100PS & 10.4 & 11.8 & 2.4 & 2.4 & 1129.7 & 1187.5 & 100.6 & 104.1 \\
\hline & $75 \mathrm{~V}$ & 12.2 & & 3.1 & & 1503.2 & & 116.7 & \\
\hline & $100 \mathrm{~V}$ & 11.3 & 11.8 & 2.8 & 2.9 & 1288.9 & 1396.1 & 100.0 & 108.3 \\
\hline & 75PV & 10.5 & & 2.7 & & 1211.9 & & 106.4 & \\
\hline & 100PV & 11.1 & 10.8 & 2.7 & 2.7 & 1269.0 & 1240.5 & 108.5 & 107.4 \\
\hline & $75 \mathrm{PS}+\mathrm{V}$ & 9.0 & & 2.6 & & 1006.5 & & 93.6 & \\
\hline & $100 P S+V$ & 11.5 & 10.3 & 2.6 & 2.6 & 1300.9 & 1153.7 & 103.4 & 98.5 \\
\hline & 75PS+PV & 11.5 & & 2.8 & & 1266.6 & & 109.6 & \\
\hline & 100PS+PV & 11.4 & 11.5 & 2.5 & 2.6 & 1156.3 & 1211.5 & 101.3 & 105.4 \\
\hline & $75 V+P V$ & 12.1 & & 2.6 & & 1309.9 & & 109.1 & \\
\hline & $100 V+P V$ & 10.8 & 11.5 & 2.7 & 2.6 & 1176.8 & 1243.3 & 98.8 & 104.0 \\
\hline \multirow[t]{16}{*}{ H3 } & NI & 10.7 & 10.7 & 2.6 & 2.6 & 1217.8 & 1217.8 & 102.5 & 102.5 \\
\hline & 75All stages & 11.0 & & 2.7 & & 1294.7 & & 104.8 & \\
\hline & 100All stages & 11.3 & 11.2 & 2.3 & 2.5 & 1156.9 & 1225.8 & 108.5 & 106.6 \\
\hline & 75PS & 10.8 & & 1.9 & & 929.7 & & 102.7 & \\
\hline & 100PS & 14.4 & 12.6 & 2.1 & 2.0 & 1779.1 & 1354.4 & 126.4 & 114.6 \\
\hline & $75 \mathrm{~V}$ & 11.5 & & 2.6 & & 1313.1 & & 107.7 & \\
\hline & $100 \mathrm{~V}$ & 10.9 & 11.2 & 2.7 & 2.6 & 1303.6 & 1308.4 & 116.4 & 112.1 \\
\hline & 75PV & 9.0 & & 3.0 & & 1173.0 & & 104.6 & \\
\hline & 100PV & 11.4 & 10.2 & 2.5 & 2.7 & 1236.9 & 1204.9 & 96.8 & 100.7 \\
\hline & $75 \mathrm{PS}+\mathrm{V}$ & 11.3 & & 2.2 & & 1096.0 & & 109.1 & \\
\hline & $100 P S+V$ & 10.6 & 11.0 & 2.8 & 2.5 & 1246.1 & 1171.1 & 107.5 & 108.3 \\
\hline & 75PS+PV & 11.9 & & 2.6 & & 1346.6 & & 117.8 & \\
\hline & 100PS+PV & 9.7 & 10.8 & 3.1 & 2.8 & 1210.3 & 1278.4 & 107.9 & 112.8 \\
\hline & $75 V+P V$ & 9.0 & & 3.1 & & 1344.9 & & 105.7 & \\
\hline & $100 V+P V$ & 11.2 & 10.1 & 3.0 & 3.0 & 1237.5 & 1291.2 & 99.0 & 102.4 \\
\hline & $\operatorname{LSD}(p=0.05)$ & 3.5900 & & 0.5 & & 313.60 & & 15.33 & \\
\hline
\end{tabular}

$\mathrm{BS}=$ Berry set; $\mathrm{PS}=$ Pea size; $\mathrm{V}=$ Véraison; $\mathrm{PV}=$ Post-véraison; $75=$ irrigated to $75 \%$ field water capacity; $100=$ irrigated to $100 \%$ field water capacity; NI = No irrigation; Trm. av. = Treatment average; H1 = Harvest $1 ; \mathrm{H} 2=$ Harvest 2; H3 = Harvest 3; Before irrigation $=$ Means of measurements at berry set

TABLE $6 b$

Effect of level and stage of irrigation on vegetative growth (secondary shoots) and the ratio of primary:secondary leaf area of Shiraz/Richter 99.

\begin{tabular}{|c|c|c|c|c|c|c|c|c|c|}
\hline \multirow[b]{2}{*}{ Stage } & \multirow{2}{*}{$\begin{array}{l}\text { Irrigation } \\
\text { treatment } \\
\text { (stage }+ \text { level) }\end{array}$} & \multicolumn{2}{|c|}{$\begin{array}{c}\text { Sec. shoots/prim. } \\
\text { shoot }\end{array}$} & \multicolumn{2}{|c|}{$\begin{array}{c}\text { Sec. leaf mass/prim. } \\
\text { shoot }\end{array}$} & \multicolumn{2}{|c|}{$\begin{array}{c}\text { Sec. leaf area/prim. } \\
\text { shoot }\end{array}$} & \multicolumn{2}{|c|}{$\begin{array}{c}\text { Prim. leaf area/sec. } \\
\text { leaf area }\end{array}$} \\
\hline & & Number & Trm. av. & (g) & Trm. av. & $\left(\mathrm{cm}^{2}\right)$ & Trm. av. & (cm) & Trm. av. \\
\hline BS & $\begin{array}{l}\text { Before } \\
\text { irrigation }\end{array}$ & 7.5 & 7.5 & 33.6 & 33.6 & 2062.1 & 2062.1 & 0.56 & 0.56 \\
\hline \multirow[t]{3}{*}{ PS } & NI & 9.8 & 9.8 & 42.2 & 42.2 & 2854.2 & 2854.2 & 0.80 & 0.80 \\
\hline & 75All stages & 10.2 & & 42.4 & & 2943.6 & & 0.68 & \\
\hline & 100All stages & 9.2 & 9.7 & 31.2 & 36.8 & 2731.8 & 2837.7 & 0.80 & 0.74 \\
\hline
\end{tabular}


TABLE $6 \mathrm{~b}$ (CONTINUED)

\begin{tabular}{|c|c|c|c|c|c|c|c|c|c|}
\hline \multirow[b]{2}{*}{ Stage } & \multirow{2}{*}{$\begin{array}{l}\text { Irrigation } \\
\text { treatment } \\
\text { (stage }+ \text { level) }\end{array}$} & \multicolumn{2}{|c|}{$\begin{array}{c}\text { Sec. shoots/prim. } \\
\text { shoot }\end{array}$} & \multicolumn{2}{|c|}{$\begin{array}{c}\text { Sec. leaf mass/prim. } \\
\text { shoot }\end{array}$} & \multicolumn{2}{|c|}{$\begin{array}{c}\text { Sec. leaf area/prim. } \\
\text { shoot }\end{array}$} & \multicolumn{2}{|c|}{$\begin{array}{c}\text { Prim. leaf area } / \mathrm{sec} . \\
\text { leaf area }\end{array}$} \\
\hline & & Number & Trm. av. & (g) & Trm. av. & $\left(\mathrm{cm}^{2}\right)$ & Trm. av. & $(\mathrm{cm})$ & Trm. av. \\
\hline \multirow[t]{5}{*}{$\mathbf{V}$} & NI & 8.9 & 8.9 & 48.0 & 48.0 & 2801.3 & 2801.3 & 0.52 & 0.52 \\
\hline & 75All stages & 12.4 & & 52.4 & & 2793.3 & & 0.65 & \\
\hline & 100All stages & 13.4 & 12.9 & 47.0 & 49.7 & 2712.7 & 2753.0 & 0.61 & 0.63 \\
\hline & 75PS & 12.8 & & 50.8 & & 3472.8 & & 0.48 & \\
\hline & 100PS & 11.7 & 12.3 & 317.5 & 184.2 & 3137.5 & 3305.2 & 0.49 & 0.48 \\
\hline \multirow[t]{9}{*}{ PV } & NI & 10.9 & 10.9 & 40.5 & 40.5 & 2299.3 & 2299.3 & 0.67 & 0.67 \\
\hline & 75All stages & 10.8 & & 52.0 & & 2884.1 & & 0.53 & \\
\hline & 100All stages & 11.4 & 11.1 & 53.5 & 52.7 & 2455.4 & 2669.7 & 0.93 & 0.73 \\
\hline & 75PS & 12.0 & & 51.9 & & 2855.7 & & 0.56 & \\
\hline & 100PS & 10.2 & 11.1 & 45.4 & 48.6 & 2478.7 & 2667.2 & 0.67 & 0.62 \\
\hline & $75 \mathrm{~V}$ & 10.5 & & 38.9 & & 2137.7 & & 0.84 & \\
\hline & $100 \mathrm{~V}$ & 11.0 & 10.8 & 42.3 & 40.6 & 2323.4 & 2230.5 & 0.78 & 0.81 \\
\hline & $75 \mathrm{PS}+\mathrm{V}$ & 11.0 & & 41.0 & & 2244.6 & & 0.73 & \\
\hline & $100 P S+V$ & 11.2 & 11.1 & 47.4 & 44.2 & 2645.4 & 2445.0 & 0.61 & 0.67 \\
\hline \multirow[t]{15}{*}{ H1 } & NI & 9.2 & 9.2 & 45.6 & 45.6 & 2501.4 & 2501.4 & 0.54 & 0.54 \\
\hline & 75All stages & 9.9 & & 44.9 & & 2422.2 & & 0.55 & \\
\hline & 100All stages & 13.5 & 11.7 & 52.4 & 48.6 & 2741.6 & 2581.9 & 0.51 & 0.53 \\
\hline & 75PS & 10.6 & & 38.4 & & 2065.6 & & 0.62 & \\
\hline & 100PS & 10.3 & 10.4 & 48.9 & 43.7 & 2647.2 & 2356.4 & 0.44 & 0.53 \\
\hline & $75 \mathrm{~V}$ & 8.8 & & 43.8 & & 2303.3 & & 0.56 & \\
\hline & $100 \mathrm{~V}$ & 9.7 & 9.2 & 44.8 & 44.3 & 2186.1 & 2244.7 & 0.56 & 0.56 \\
\hline & 75PV & 10.0 & & 35.1 & & 1938.4 & & 0.76 & \\
\hline & 100PV & 9.7 & 9.8 & 32.9 & 34.0 & 1799.0 & 1868.7 & 0.78 & 0.77 \\
\hline & 75PS+V & 8.8 & & 39.5 & & 2065.1 & & 0.66 & \\
\hline & $100 P S+V$ & 11.7 & 10.2 & 40.7 & 40.1 & 2187.5 & 2126.3 & 0.75 & 0.71 \\
\hline & 75PS+PV & 9.3 & & 44.5 & & 2416.5 & & 0.53 & \\
\hline & 100PS+PV & 8.9 & 9.1 & 33.3 & 38.9 & 1822.7 & 2119.6 & 0.67 & 0.60 \\
\hline & $75 \mathrm{~V}+\mathrm{PV}$ & 9.9 & & 41.3 & & 2208.1 & & 0.59 & \\
\hline & $100 V+P V$ & 9.3 & 9.6 & 31.0 & 36.1 & 1614.2 & 1911.1 & 0.86 & 0.73 \\
\hline \multirow[t]{15}{*}{ H2 } & NI & 10.8 & 10.8 & 44.4 & 44.4 & 2568.4 & 2568.4 & 0.60 & 0.60 \\
\hline & 75All stages & 11.3 & & 52.9 & & 2816.6 & & 0.67 & \\
\hline & 100All stages & 11.5 & 11.4 & 39.5 & 46.2 & 2124.7 & 2470.7 & 0.62 & 0.64 \\
\hline & 75PS & 11.7 & & 43.2 & & 2242.9 & & 0.59 & \\
\hline & 100PS & 10.6 & 11.2 & 42.7 & 43.0 & 2286.4 & 2264.6 & 0.50 & 0.54 \\
\hline & $75 \mathrm{~V}$ & 11.7 & & 46.1 & & 2454.5 & & 0.59 & \\
\hline & $100 \mathrm{~V}$ & 9.4 & 10.5 & 37.2 & 41.6 & 1861.1 & 2157.8 & 0.88 & 0.73 \\
\hline & 75PV & 9.3 & & 40.8 & & 2162.7 & & 0.65 & \\
\hline & 100PV & 10.8 & 10.0 & 39.8 & 40.3 & 1964.9 & 2063.8 & 0.72 & 0.68 \\
\hline & $75 \mathrm{PS}+\mathrm{V}$ & 9.4 & & 38.6 & & 2016.4 & & 0.62 & \\
\hline & $100 P S+V$ & 11.1 & 10.3 & 35.2 & 36.9 & 2066.7 & 2041.6 & 0.69 & 0.65 \\
\hline & 75PS+PV & 9.6 & & 35.4 & & 1922.3 & & 0.73 & \\
\hline & 100PS+PV & 10.4 & 10.0 & 44.1 & 39.8 & 2335.0 & 2128.6 & 0.60 & 0.67 \\
\hline & $75 \mathrm{~V}+\mathrm{PV}$ & 9.6 & & 38.1 & & 1950.9 & & 0.79 & \\
\hline & $100 V+P V$ & 9.3 & 9.5 & 35.0 & 36.5 & 1859.5 & 1905.2 & 0.90 & 0.85 \\
\hline
\end{tabular}


TABLE $6 \mathrm{~b}$ (CONTINUED)

\begin{tabular}{|c|c|c|c|c|c|c|c|c|c|}
\hline \multirow[b]{2}{*}{ Stage } & \multirow{2}{*}{$\begin{array}{l}\text { Irrigation } \\
\text { treatment } \\
\text { (stage + level) }\end{array}$} & \multicolumn{2}{|c|}{$\begin{array}{l}\text { Sec. shoots/prim. } \\
\text { shoot }\end{array}$} & \multicolumn{2}{|c|}{$\begin{array}{c}\text { Sec. leaf mass/prim. } \\
\text { shoot }\end{array}$} & \multicolumn{2}{|c|}{$\begin{array}{c}\text { Sec. leaf area/prim. } \\
\text { shoot }\end{array}$} & \multicolumn{2}{|c|}{$\begin{array}{c}\text { Prim. leaf area/sec. } \\
\text { leaf area }\end{array}$} \\
\hline & & Number & Trm. av. & (g) & Trm. av. & $\left(\mathrm{cm}^{2}\right)$ & Trm. av. & (cm) & Trm. av. \\
\hline \multirow[t]{16}{*}{ H3 } & NI & 9.1 & 9.1 & 44.1 & 44.1 & 2392.1 & 2392.1 & 0.56 & 0.56 \\
\hline & 75All stages & 10.0 & & 44.4 & & 2349.5 & & 0.59 & \\
\hline & 100All stages & 12.1 & 11.0 & 39.3 & 41.8 & 2209.1 & 2279.3 & 0.55 & 0.57 \\
\hline & 75PS & 10.0 & & 33.8 & & 1847.1 & & 0.56 & \\
\hline & 100PS & 12.3 & 11.2 & 44.2 & 39.0 & 2533.4 & 2190.3 & 0.72 & 0.64 \\
\hline & $75 \mathrm{~V}$ & 10.3 & & 33.6 & & 1949.8 & & 0.77 & \\
\hline & $100 \mathrm{~V}$ & 11.4 & 10.8 & 40.6 & 37.1 & 2214.0 & 2081.9 & 0.68 & 0.73 \\
\hline & $75 \mathrm{PV}$ & 8.9 & & 34.3 & & 2116.0 & & 0.64 & \\
\hline & $100 \mathrm{PV}$ & 10.3 & 9.6 & 38.6 & 36.5 & 2112.3 & 2114.1 & 0.68 & 0.66 \\
\hline & $75 \mathrm{PS}+\mathrm{V}$ & 10.3 & & 28.9 & & 1647.3 & & 0.71 & \\
\hline & $100 P S+V$ & 9.1 & 9.7 & 35.5 & 32.2 & 1993.3 & 1820.3 & 0.72 & 0.71 \\
\hline & 75PS+PV & 9.9 & & 33.2 & & 1832.5 & & 0.83 & \\
\hline & 100PS+PV & 10.3 & 10.1 & 40.4 & 36.8 & 2218.0 & 2025.2 & 0.63 & 0.73 \\
\hline & $75 \mathrm{~V}+\mathrm{PV}$ & 9.7 & & 42.2 & & 2292.5 & & 0.66 & \\
\hline & $100 \mathrm{~V}+\mathrm{PV}$ & 8.8 & 9.3 & 43.6 & 42.9 & 2307.0 & 2299.7 & 0.78 & 0.72 \\
\hline & $\operatorname{LSD}(p=0.05)$ & 2.364 & & 14.2 & & 815.010 & & 0.295 & \\
\hline
\end{tabular}

$\mathrm{BS}=$ Berry set; $\mathrm{PS}=$ Pea size; $\mathrm{V}=$ Véraison; $\mathrm{PV}=$ Post-véraison; Prim. $=$ Primary; 75 = irrigated to $75 \%$ field water capacity; $100=$ irrigated to $100 \%$ field water capacity; $\mathrm{NI}=$ No irrigation; Trm. av. $=$ Treatment average; $\mathrm{H} 1=$ Harvest $1 ; \mathrm{H} 2=$ Harvest 2; H3 = Harvest 3; Before irrigation $=$ Means of measurements at berry set

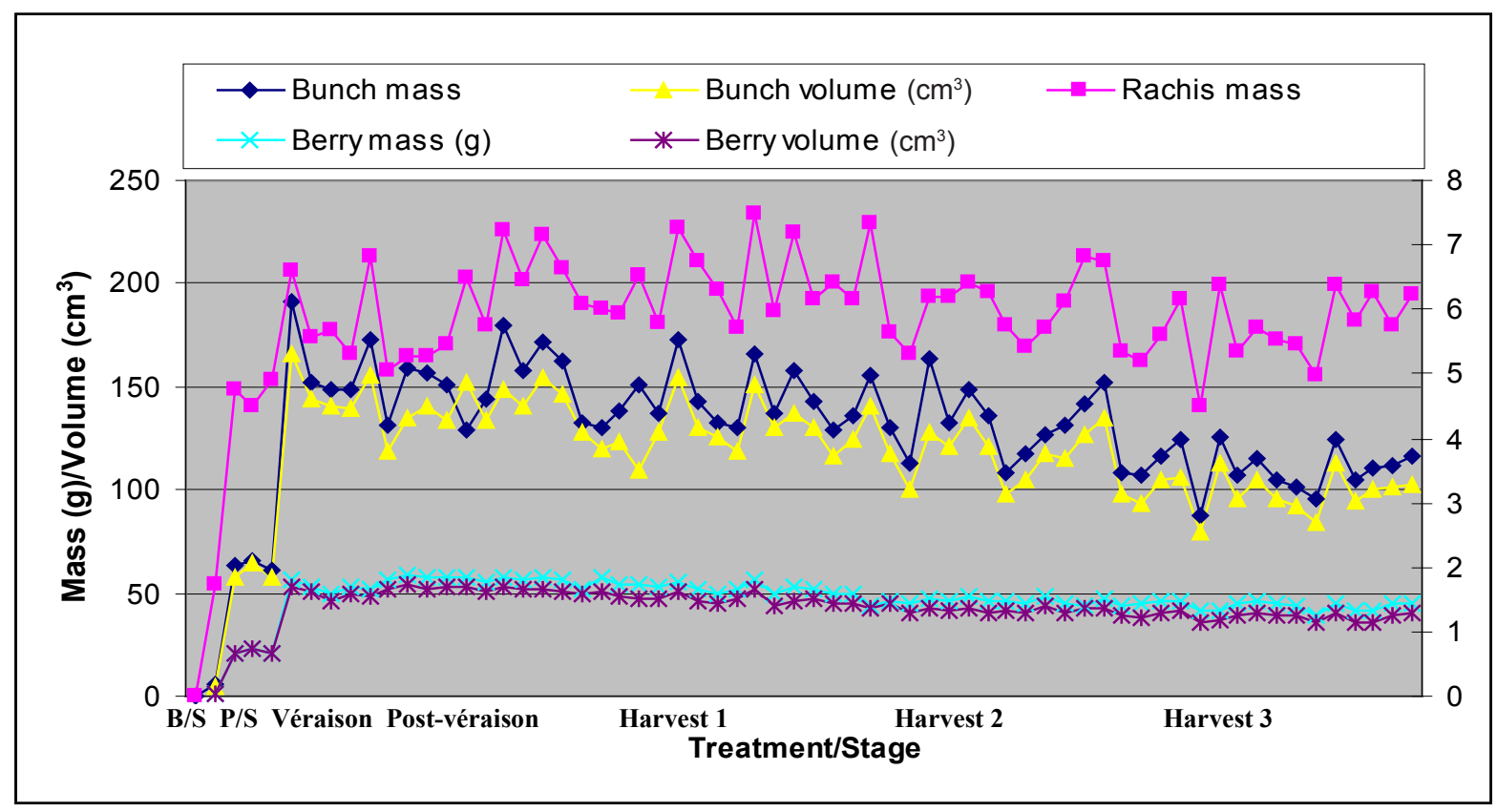

FIGURE 6

Trends in the evolution of bunch, rachis and berry parameters of Shiraz/Richter 99 over stages.

characteristics. An apparent sudden build-up of sucrose in the rachis during ripening certainly has value as a simple indicator of optimal ripeness/berry inactivity and harvest potential of the grapes. This should be investigated further.

\section{Berry composition}

A general trend of more water and less concentrated soluble solids occurred (Table 8). The NI vines did not seem able to reach similar soluble solid concentrations than the irrigated vines, especially up to the last harvest stage, but the values compared well to those of the high volume fully irrigated vines. As referred to earlier, the vines seemed to display an increasing independence of $\mathrm{Sw}$ as ripening proceeded. At the same time, the senescing canopy apparently produced 
less and hoarded more sucrose and the berries lost more water than they could gain from $\Psi$ gradients. Although the soluble solid concentration increased with further ripening, the soluble solid content per berry reached a plateau from approximately $22^{\circ} \mathrm{B}$, which was preceded by a very fast import/accumulation from $\mathrm{V}$ until three weeks after (PV). This therefore is a critical period in transport to and accumulation in the berry. In a previous study it was found that the linear relationship between sugar transport and accumulation was broken earlier under conditions of soil water reduction (Hunter \& Deloire, 2005); this is also evident at the last harvest stage in this study. The berry therefore concentrated (both pulp and skin) during this period, but at the same time lost mass as a result of water loss and reduced phloem sugar and water transport. From Fig. 9 it is clear that the general rachis:pulp+skin sucrose ratio (over all treatments) increased with ripening, especially at the last harvest stage, indicating reduced demand and restricted transport to and unloading into the berry.

\section{General physiological trends}

For the Shiraz in this study, shrinkage of the berries continued during (especially late) ripening, irrespective of highly negative $\Psi$ prevailing in the berry during this period (as also found by Rogiers et al., 2006 \& Greer \& Rogiers, 2009), which may have been expected to facilitate sustained water flow to the berry. The signal of low turgor status of the pericarp cells is apparently not transmitted to the parent vine (including the pedicel), and the berry seems to become at least partly isolated at such time. No clear evidence could be found that even high volumes of water (to $100 \% \mathrm{FWC}$ ) during ripening could sustain berry volume, indicating that not only is the berry less sensitive to water deficit during ripening (as compared to the pre-véraison period - Greenspan et al., 1994, 1996), but it also seems not to be affected by high volumes of water during this time. This is partly in line with the findings of Keller et al. (2006). However, they deducted from their studies that watering during ripening would prevent further shrinkage of the berries. In our study, berries continued to lose water, irrespectively. Although it is acknowledged that the field conditions in this comprehensive study may not be considered ideal for studying basic physiological processes, clear trends were found. If it is accepted that the cell can only regulate its water balance (turgor) by actively regulating the osmotic potential, solute accumulation and metabolism are bound to play a significant role. In addition, the $\Psi$ gradients and hydraulic conductivity of the transport pathway are critical in the influx of water and thus the maintenance of turgor (Patrick, 1997; Tilbrook \& Tyerman, 2009). Although, by lack of sufficient information, sucrose is considered the main role player, sucrose and $\mathrm{K}$ plus accompanying anions represent the major osmotic species translocated in the phloem sap (Patrick, 1997). With K being the most abundant cation, its accumulation certainly also has a role in maintaining berry turgor (Mpelasoka et al., 2003). Co-expression of some aquaporins and sugar transporters involved in sugar and water trans-cellular flux also assumes a link that is functional in unloading and accumulation in berry flesh vacuoles (Delrot et al., 2001; Conde et al., 2006; Fouquet et al., 2008; Zhang et al., 2008). According to Glissant et al. (2008), aquaporin expression follows a complex developmental pattern that probably contributes

TABLE 7

Effect of level and stage of irrigation on reproductive growth of Shiraz/Richter 99.

\begin{tabular}{|c|c|c|c|c|c|c|c|c|c|c|c|c|}
\hline \multirow[b]{2}{*}{ Stage } & \multirow[b]{2}{*}{$\begin{array}{l}\text { Irrigation } \\
\text { treatment }\end{array}$} & \multirow{2}{*}{$\begin{array}{c}\text { Bunch } \\
\text { no./ } \\
\text { shoot }\end{array}$} & \multicolumn{4}{|c|}{ Bunch } & \multicolumn{2}{|c|}{ Rachis } & \multicolumn{3}{|c|}{ Berry } & \multirow{2}{*}{$\begin{array}{c}\text { Bunch: } \\
\text { Rachis } \\
\text { mass }\end{array}$} \\
\hline & & & $\begin{array}{c}\text { Mass } \\
(\mathrm{g})\end{array}$ & $\begin{array}{l}\text { Vol. } \\
\left(\mathrm{cm}^{3}\right)\end{array}$ & $\begin{array}{c}\text { Length } \\
(\mathrm{cm})\end{array}$ & $\begin{array}{c}\text { Width } \\
(\mathrm{cm})\end{array}$ & $\begin{array}{c}\text { Mass } \\
\text { (g) }\end{array}$ & $\begin{array}{c}\text { Vol. } \\
\left(\mathrm{cm}^{3}\right)\end{array}$ & $\begin{array}{c}\text { Mass } \\
(\mathrm{g})\end{array}$ & $\begin{array}{c}\text { No./ } \\
\text { bunch }\end{array}$ & $\begin{array}{c}\text { Vol. } \\
\left(\mathrm{cm}^{3}\right)\end{array}$ & \\
\hline BS & Before I & 1.45 & 5.35 & 5.1 & 11.20 & 3.41 & 1.74 & 1.88 & 0.05 & $*$ & 0.05 & 3.1 \\
\hline \multirow[t]{3}{*}{ PS } & NI & 1.46 & 63.21 & 57.9 & 15.83 & 6.01 & 4.75 & 4.89 & 0.67 & 75.0 & 0.67 & 13.3 \\
\hline & 75All & 1.68 & 65.46 & 64.0 & 13.98 & 6.29 & 4.50 & 4.62 & 0.75 & 77.3 & 0.74 & 14.5 \\
\hline & 100All & 1.50 & 61.56 & 58.0 & 13.00 & 5.64 & 4.89 & 4.68 & 0.68 & 79.7 & 0.68 & 12.6 \\
\hline \multirow[t]{5}{*}{$\mathbf{V}$} & NI & 1.57 & 191.67 & 165.9 & 15.90 & 8.64 & 6.61 & 6.41 & 1.81 & 111.5 & 1.71 & 29.0 \\
\hline & 75All & 1.96 & 151.85 & 143.6 & 15.05 & 7.54 & 5.58 & 5.28 & 1.71 & 97.0 & 1.61 & 27.2 \\
\hline & 100All & 1.64 & 148.07 & 141.1 & 14.65 & 7.77 & 5.66 & 5.34 & 1.60 & 95.0 & 1.49 & 26.1 \\
\hline & 75PS & 1.64 & 148.76 & 138.9 & 14.76 & 8.08 & 5.31 & 5.07 & 1.68 & 95.9 & 1.59 & 28.0 \\
\hline & 100PS & 1.68 & 173.26 & 155.3 & 16.28 & 8.60 & 6.81 & 6.66 & 1.67 & 115.4 & 1.56 & 25.5 \\
\hline \multirow[t]{9}{*}{ PV } & NI & 1.71 & 131.48 & 118.6 & 14.48 & 6.80 & 5.05 & 7.40 & 1.81 & 78.0 & 1.66 & 26.0 \\
\hline & 75All & 1.93 & 158.95 & 134.5 & 14.44 & 7.37 & 5.28 & 5.44 & 1.89 & 91.9 & 1.74 & 30.1 \\
\hline & 100All & 1.57 & 151.50 & 140.2 & 13.69 & 6.88 & 5.28 & 5.76 & 1.86 & 96.3 & 1.65 & 28.7 \\
\hline & 75PS & 1.75 & 150.90 & 133.5 & 16.74 & 6.90 & 5.46 & 5.21 & 1.84 & 90.4 & 1.68 & 27.6 \\
\hline & 100PS & 1.86 & 174.29 & 152.1 & 15.04 & 7.74 & 6.49 & 6.41 & 1.84 & 101.7 & 1.68 & 26.9 \\
\hline & $75 \mathrm{~V}$ & 1.54 & 143.54 & 133.2 & 14.23 & 7.27 & 5.74 & 7.33 & 1.77 & 90.6 & 1.63 & 25.0 \\
\hline & $100 \mathrm{~V}$ & 1.57 & 180.25 & 149.0 & 14.85 & 8.11 & 7.22 & 7.24 & 1.83 & 104.5 & 1.68 & 25.0 \\
\hline & $75 \mathrm{PS}+\mathrm{V}$ & 1.64 & 157.76 & 140.4 & 15.42 & 7.64 & 6.46 & 6.64 & 1.82 & 97.1 & 1.65 & 24.4 \\
\hline & $100 \mathrm{PS}+\mathrm{V}$ & 1.86 & 171.81 & 154.1 & 15.22 & 7.69 & 7.15 & 6.71 & 1.84 & 102.9 & 1.67 & 24.0 \\
\hline
\end{tabular}




\begin{tabular}{|c|c|c|c|c|c|c|c|c|c|c|c|c|}
\hline \multirow[b]{2}{*}{ Stage } & \multirow[b]{2}{*}{$\begin{array}{l}\text { Irrigation } \\
\text { treatment }\end{array}$} & \multirow{2}{*}{$\begin{array}{c}\text { Bunch } \\
\text { no./ } \\
\text { shoot }\end{array}$} & \multicolumn{4}{|c|}{ Bunch } & \multicolumn{2}{|c|}{ Rachis } & \multicolumn{3}{|c|}{ Berry } & \multirow{2}{*}{$\begin{array}{c}\text { Bunch: } \\
\text { Rachis } \\
\text { mass }\end{array}$} \\
\hline & & & $\begin{array}{c}\text { Mass } \\
(\mathrm{g}) \\
\end{array}$ & $\begin{array}{c}\text { Vol. } \\
\left(\mathrm{cm}^{3}\right)\end{array}$ & $\begin{array}{c}\text { Length } \\
(\mathrm{cm})\end{array}$ & $\begin{array}{l}\text { Width } \\
(\mathrm{cm})\end{array}$ & $\begin{array}{c}\text { Mass } \\
(\mathrm{g}) \\
\end{array}$ & $\begin{array}{c}\text { Vol. } \\
\left(\mathrm{cm}^{3}\right)\end{array}$ & $\begin{array}{c}\text { Mass } \\
(\mathrm{g}) \\
\end{array}$ & $\begin{array}{c}\text { No./ } \\
\text { bunch }\end{array}$ & $\begin{array}{c}\text { Vol. } \\
\left(\mathrm{cm}^{3}\right)\end{array}$ & \\
\hline \multirow[t]{15}{*}{ H1 } & NI & 1.50 & 162.27 & 146.0 & 15.44 & 7.60 & 6.62 & 5.83 & 1.79 & 108.6 & 1.62 & 24.5 \\
\hline & 75All & 1.54 & 132.59 & 127.6 & 14.04 & 6.83 & 6.09 & 4.61 & 1.67 & 92.3 & 1.57 & 21.8 \\
\hline & 100All & 1.54 & 130.76 & 119.3 & 14.22 & 7.12 & 6.00 & 5.20 & 1.83 & 88.6 & 1.64 & 21.8 \\
\hline & 75PS & 1.61 & 137.93 & 123.0 & 14.93 & 7.30 & 5.95 & 5.41 & 1.72 & 95.2 & 1.53 & 23.2 \\
\hline & 100PS & 1.43 & 150.51 & 109.0 & 14.71 & 7.37 & 6.54 & 5.81 & 1.73 & 114.7 & 1.51 & 23.0 \\
\hline & $75 \mathrm{~V}$ & 1.50 & 136.64 & 127.4 & 14.42 & 7.45 & 5.80 & 5.29 & 1.68 & 94.4 & 1.52 & 23.6 \\
\hline & $100 \mathrm{~V}$ & 1.50 & 172.51 & 154.8 & 15.49 & 8.08 & 7.25 & 8.91 & 1.77 & 107.8 & 1.61 & 23.8 \\
\hline & 75PV & 1.64 & 143.36 & 129.7 & 14.56 & 7.20 & 6.74 & 5.82 & 1.65 & 101.1 & 1.46 & 21.3 \\
\hline & 100PV & 1.57 & 132.46 & 125.6 & 13.99 & 6.63 & 6.32 & 5.36 & 1.60 & 92.6 & 1.43 & 20.9 \\
\hline & $75 P S+V$ & 1.68 & 130.56 & 118.6 & 13.77 & 6.83 & 5.71 & 5.32 & 1.67 & 94.0 & 1.50 & 22.9 \\
\hline & $100 P S+V$ & 1.64 & 165.41 & 150.9 & 14.96 & 7.04 & 7.48 & 6.68 & 1.82 & 101.2 & 1.66 & 22.1 \\
\hline & 75PS+PV & 1.57 & 136.88 & 130.6 & 13.99 & 7.28 & 5.97 & 5.59 & 1.58 & 97.0 & 1.41 & 22.9 \\
\hline & $100 P S+P V$ & 1.64 & 157.51 & 137.2 & 14.03 & 6.70 & 7.19 & 6.62 & 1.71 & 108.4 & 1.49 & 21.9 \\
\hline & $75 \mathrm{~V}+\mathrm{PV}$ & 1.75 & 143.08 & 130.3 & 13.83 & 6.78 & 6.15 & 5.27 & 1.67 & 93.0 & 1.50 & 23.3 \\
\hline & $100 V+P V$ & 1.82 & 129.40 & 116.9 & 14.19 & 6.71 & 6.41 & 5.75 & 1.58 & 86.8 & 1.44 & 20.2 \\
\hline \multirow[t]{15}{*}{ H2 } & NI & 1.79 & 135.71 & 124.0 & 15.77 & 9.01 & 6.17 & 5.73 & 1.59 & 99.9 & 1.43 & 22.0 \\
\hline & 75All & 1.64 & 155.61 & 140.1 & 16.34 & 8.25 & 7.33 & 6.27 & 1.41 & 103.7 & 1.38 & 21.2 \\
\hline & 100All & 1.43 & 129.69 & 117.6 & 14.57 & 7.38 & 5.63 & 5.01 & 1.48 & 96.4 & 1.45 & 23.0 \\
\hline & 75PS & 1.70 & 112.59 & 100.7 & 14.23 & 7.01 & 5.32 & 4.63 & 1.45 & 86.2 & 1.29 & 21.2 \\
\hline & 100PS & 1.43 & 163.20 & 127.9 & 15.57 & 7.61 & 6.20 & 5.28 & 1.52 & 105.0 & 1.37 & 26.3 \\
\hline & $75 \mathrm{~V}$ & 1.82 & 133.06 & 121.1 & 16.15 & 7.49 & 6.21 & 5.38 & 1.49 & 102.1 & 1.34 & 21.4 \\
\hline & $100 \mathrm{~V}$ & 1.64 & 148.63 & 134.5 & 16.28 & 7.85 & 6.40 & 6.05 & 1.55 & 107.3 & 1.38 & 23.2 \\
\hline & $75 \mathrm{PV}$ & 1.57 & 135.56 & 120.7 & 16.02 & 7.75 & 6.27 & 5.74 & 1.46 & 108.3 & 1.30 & 21.6 \\
\hline & $100 \mathrm{PV}$ & 1.54 & 108.76 & 97.6 & 14.37 & 7.19 & 5.74 & 4.85 & 1.49 & 86.4 & 1.32 & 18.9 \\
\hline & 75PS+V & 1.54 & 117.85 & 105.0 & 15.49 & 7.22 & 5.41 & 5.29 & 1.45 & 95.7 & 1.28 & 21.8 \\
\hline & $100 P S+V$ & 1.64 & 126.99 & 117.7 & 14.90 & 7.14 & 5.72 & 5.15 & 1.56 & 92.2 & 1.40 & 22.2 \\
\hline & 75PS+PV & 1.71 & 130.99 & 115.2 & 15.13 & 8.05 & 6.12 & 5.38 & 1.45 & 101.7 & 1.29 & 21.4 \\
\hline & $100 P S+P V$ & 1.68 & 141.54 & 126.7 & 15.63 & 7.33 & 6.81 & 6.43 & 1.41 & 99.5 & 1.36 & 20.8 \\
\hline & $75 \mathrm{~V}+\mathrm{PV}$ & 1.64 & 151.75 & 135.0 & 16.47 & 8.01 & 6.76 & 6.10 & 1.51 & 113.9 & 1.36 & 22.5 \\
\hline & $100 \mathrm{~V}+\mathrm{PV}$ & 1.29 & 107.96 & 97.9 & 13.78 & 6.75 & 5.36 & 4.72 & 1.39 & 87.3 & 1.24 & 20.1 \\
\hline \multirow[t]{16}{*}{ H3 } & NI & 1.64 & 107.27 & 93.6 & 14.41 & 6.17 & 5.20 & 4.94 & 1.42 & 94.3 & 1.23 & 20.6 \\
\hline & 75All & 1.71 & 115.92 & 104.7 & 15.05 & 7.70 & 5.62 & 4.44 & 1.46 & 97.2 & 1.29 & 20.6 \\
\hline & 100All & 1.36 & 124.21 & 105.5 & 15.29 & 6.86 & 6.15 & 5.49 & 1.49 & 102.6 & 1.33 & 20.2 \\
\hline & 75PS & 1.46 & 87.32 & 79.4 & 12.85 & 5.90 & 4.48 & 3.77 & 1.32 & 83.8 & 1.15 & 19.5 \\
\hline & 100PS & 1.79 & 125.75 & 113.1 & 15.48 & 7.49 & 6.37 & 5.40 & 1.34 & 105.2 & 1.18 & 19.7 \\
\hline & $75 \mathrm{~V}$ & 1.64 & 106.93 & 96.0 & 15.14 & 7.11 & 5.35 & 5.18 & 1.43 & 94.4 & 1.26 & 20.0 \\
\hline & $100 \mathrm{~V}$ & 1.71 & 114.75 & 105.1 & 15.29 & 7.34 & 5.71 & 4.85 & 1.48 & 98.2 & 1.29 & 20.1 \\
\hline & $75 \mathrm{PV}$ & 1.79 & 105.29 & 95.3 & 14.76 & 7.34 & 5.54 & 4.61 & 1.42 & 95.0 & 1.26 & 19.0 \\
\hline & 100PV & 1.75 & 101.89 & 92.2 & 13.93 & 6.78 & 5.46 & 4.95 & 1.40 & 84.6 & 1.24 & 18.6 \\
\hline & 75PS+V & 1.48 & 95.88 & 84.2 & 14.29 & 6.50 & 4.99 & 4.32 & 1.26 & 89.6 & 1.13 & 19.2 \\
\hline & $100 P S+V$ & 1.61 & 124.18 & 113.3 & 14.22 & 7.20 & 6.38 & 5.55 & 1.45 & 105.4 & 1.30 & 19.5 \\
\hline & 75PS+PV & 1.86 & 104.54 & 94.6 & 15.02 & 6.99 & 5.82 & 5.58 & 1.31 & 86.8 & 1.16 & 18.0 \\
\hline & 100PS+PV & 1.68 & 110.41 & 99.8 & 14.19 & 6.74 & 6.25 & 5.73 & 1.31 & 92.5 & 1.15 & 17.7 \\
\hline & $75 \mathrm{~V}+\mathrm{PV}$ & 1.71 & 112.04 & 101.4 & 14.80 & 7.13 & 5.75 & 5.26 & 1.44 & 99.7 & 1.27 & 19.5 \\
\hline & $100 V+P V$ & 1.75 & 116.72 & 102.1 & 15.56 & 7.19 & 6.24 & 5.59 & 1.42 & 103.7 & 1.28 & 18.7 \\
\hline & $L S D(p=0.05)$ & 0.2876 & 27.25 & 27.27 & 1.79 & 1.19 & 1.31 & 2.19 & 0.16 & 21.0 & 0.14 & 1.31 \\
\hline
\end{tabular}

$\mathrm{BS}=$ Berry set; $\mathrm{PS}=$ Pea size; $\mathrm{V}=$ Véraison; $\mathrm{PV}=$ Post-véraison; Trm. av. = Treatment average; $75=75 \%$ field water capacity irrigation; $100=100 \%$ field water capacity irrigation; $\mathrm{NI}=$ No irrigation; $\mathrm{H} 1=$ Harvest 1 ; H2 = Harvest 2; H3= Harvest 3; Before irrigation $(\mathrm{I})=$ Means of measurements at berry set 
to the diversity of its expression in different organs in response to water stress. The inhibition of phloem unloading, e.g. by down-regulation of ATP-ase, sucrose and hexose transporters, and $\mathrm{K}$ carriers have also been mentioned as mechanisms for decreased phloem flow during late ripening (Rogiers et al., 2006, and references therein). Over and above the implication that ABA may be involved in triggering berry ripening (Coombe, 1992), it also has been related to the enhancement of sink (grape bunch) strength and the direction of photo-assimilates, impacting on total yield biomass and secondary metabolites, such as anthocyanins (Hunter et al., 1991; Hiratsuka et al., 2001; Quiroga et al., 2009). From a general point of view, it seems logical that gibberellic acid also have a role to play in the ripening process, implicated by the higher seed number associated with a larger berry (Barbagallo et al., 2011). Although addressing general plant metabolism, xylem cytokinins were implicated in nutritional signalling and phloem cytokinins in sink strength regulation (Kamínek et al., 2006). This may have implications for grape berry development and ripening, particularly with regard to the fluctuation in importance of the berry as a sink during the season and late ripening, and the regulation of phloem/xylem mobility of minerals such as calcium and potassium, which can also have a large impact on organic acid salt formation and, from a practical point of view, on the $\mathrm{pH}$ of the juice. The latter could also lead to changes in anthocyanin intensity.

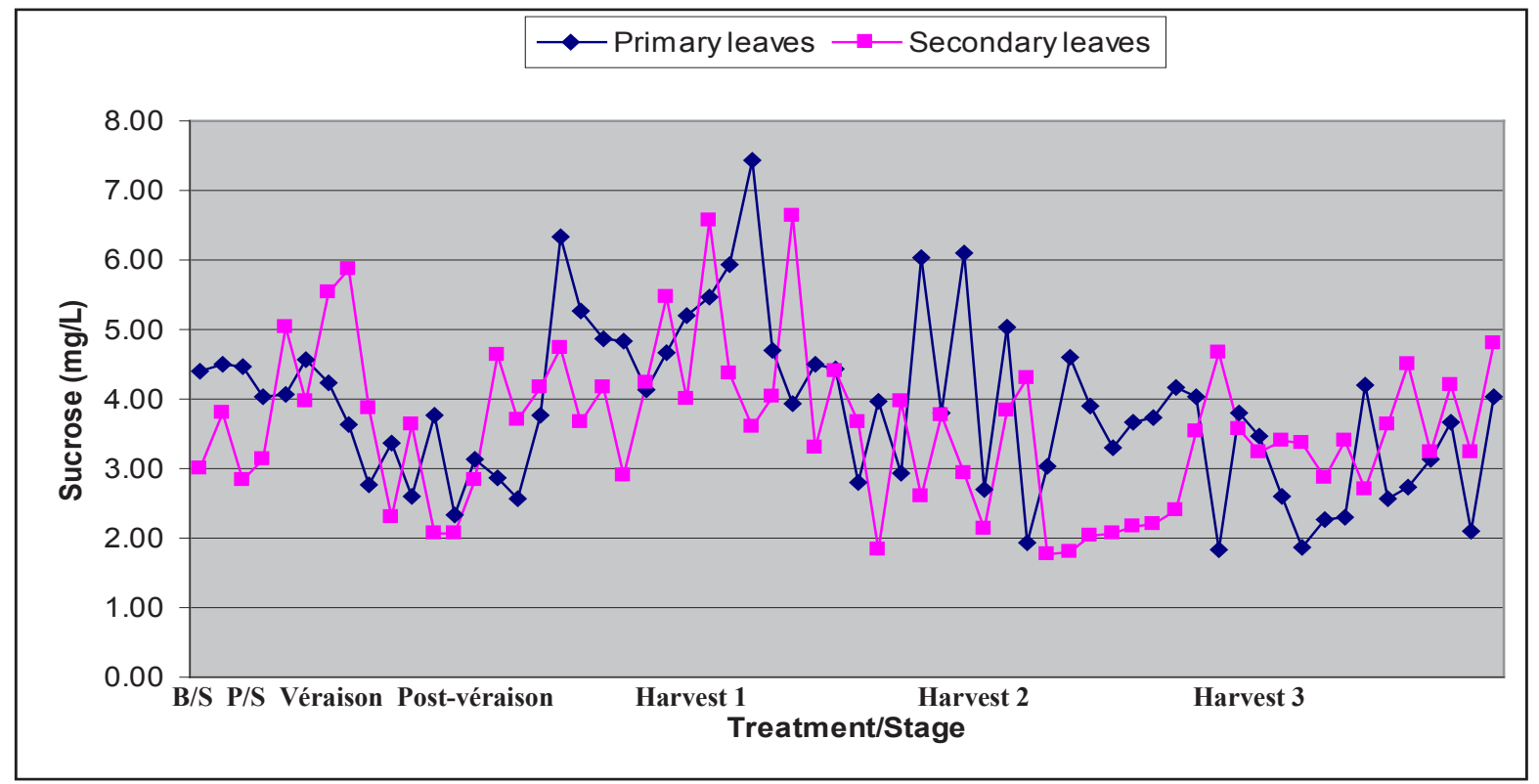

FIGURE 7

Trends in the evolution of sucrose contents of primary and secondary leaves of Shiraz/Richter 99 over stages.

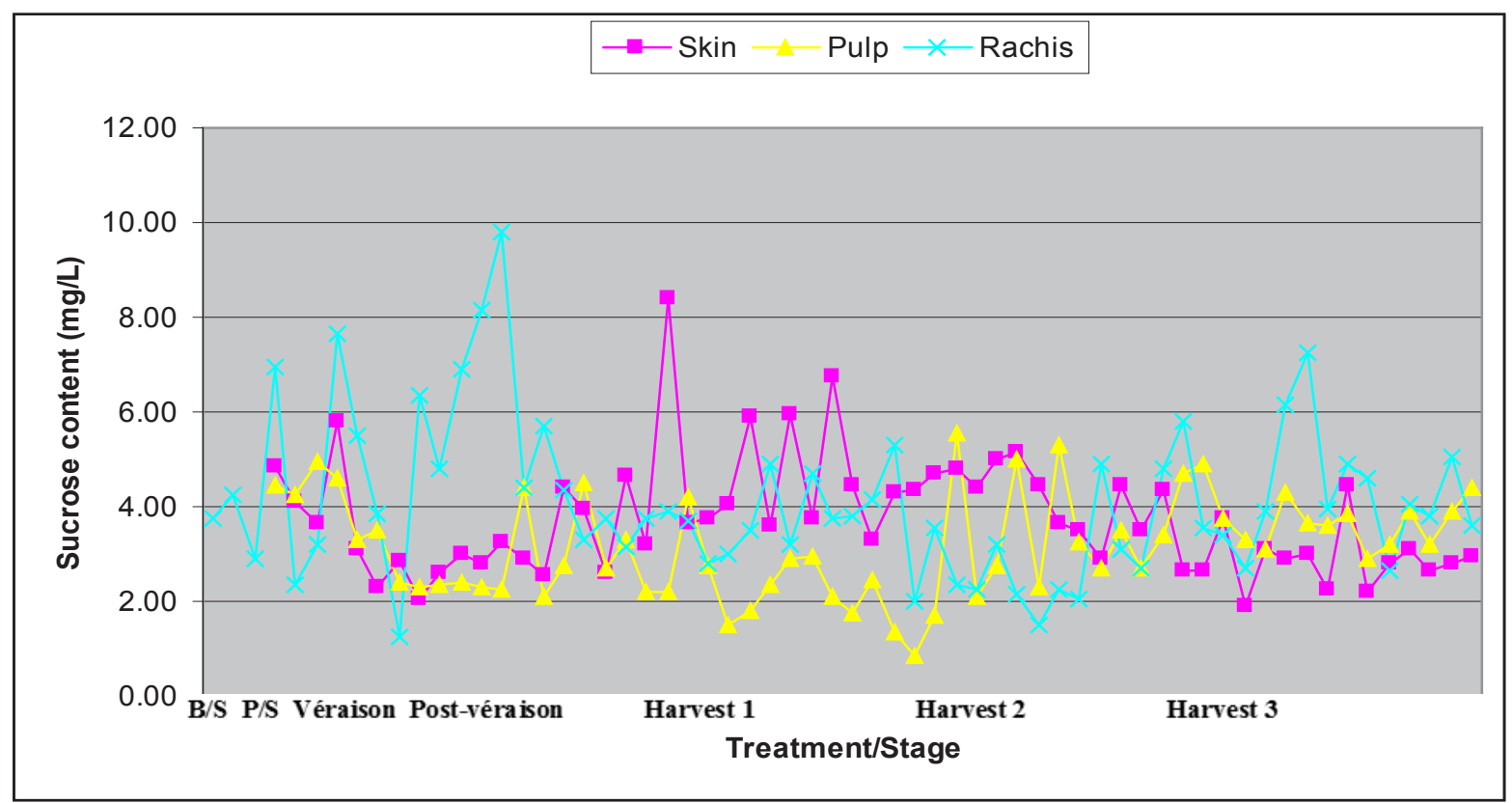

FIGURE 8

Trends in the evolution of sucrose contents of bunch parameters of Shiraz/Richter 99 over stages. 
TABLE 8

Effect of level and stage of irrigation on grape must and berry skin contents of Shiraz/Richter 99.

\begin{tabular}{|c|c|c|c|c|}
\hline Stage & $\begin{array}{c}\text { Irrigation Treatment } \\
\text { (stage+level) }\end{array}$ & Total soluble solids $\left({ }^{0} \mathrm{~B}\right)$ & $\begin{array}{c}\text { Soluble solid content/ } \\
\text { berry (g) }\end{array}$ & $\begin{array}{c}\text { Skin water } \\
(\%)\end{array}$ \\
\hline \multirow[t]{5}{*}{$\mathbf{V}$} & NI & 12.3 & 0.22 & 76.2 \\
\hline & 75All stages & 10.6 & 0.18 & 75.9 \\
\hline & 100All stages & 11.2 & 0.18 & 74.8 \\
\hline & 75PS & 11.2 & 0.19 & 75.2 \\
\hline & 100PS & 10.6 & 0.18 & 76.6 \\
\hline \multirow[t]{9}{*}{ PV } & NI & 19.6 & 0.35 & 71.6 \\
\hline & 75All stages & 18.7 & 0.35 & 73.9 \\
\hline & 100All stages & 18.0 & 0.33 & 73.7 \\
\hline & 75PS & 20.9 & 0.38 & 71.0 \\
\hline & 100PS & 18.3 & 0.34 & 72.4 \\
\hline & $75 \mathrm{~V}$ & 20.1 & 0.35 & 71.8 \\
\hline & $100 \mathrm{~V}$ & 19.0 & 0.35 & 72.6 \\
\hline & 75PS $+\mathrm{V}$ & 20.0 & 0.36 & 70.9 \\
\hline & $100 P S+V$ & 18.3 & 0.34 & 72.1 \\
\hline \multirow[t]{15}{*}{ H1 } & NI & 21.6 & 0.39 & 70.3 \\
\hline & 75All stages & 21.3 & 0.35 & 70.5 \\
\hline & 100All stages & 21.0 & 0.38 & 71.0 \\
\hline & 75PS & 23.3 & 0.40 & 67.8 \\
\hline & 100PS & 21.8 & 0.38 & 70.1 \\
\hline & $75 \mathrm{~V}$ & 22.4 & 0.38 & 69.3 \\
\hline & $100 \mathrm{~V}$ & 21.7 & 0.38 & 70.0 \\
\hline & 75PV & 23.0 & 0.38 & 69.6 \\
\hline & 100PV & 22.5 & 0.36 & 68.2 \\
\hline & $75 \mathrm{PS}+\mathrm{V}$ & 22.0 & 0.37 & 68.3 \\
\hline & $100 P S+V$ & 20.2 & 0.37 & 71.4 \\
\hline & 75PS+PV & 22.5 & 0.35 & 68.9 \\
\hline & 100PS+PV & 21.9 & 0.37 & 69.8 \\
\hline & $75 V+P V$ & 22.5 & 0.38 & 68.8 \\
\hline & $100 \mathrm{~V}+\mathrm{PV}$ & 20.5 & 0.32 & 70.9 \\
\hline \multirow[t]{15}{*}{ H2 } & NI & 25.1 & 0.40 & 65.9 \\
\hline & 75All stages & 24.6 & 0.35 & 67.9 \\
\hline & 100All stages & 24.1 & 0.36 & 66.5 \\
\hline & 75PS & 25.8 & 0.37 & 64.9 \\
\hline & 100PS & 25.5 & 0.39 & 66.0 \\
\hline & $75 \mathrm{~V}$ & 25.3 & 0.38 & 66.0 \\
\hline & $100 \mathrm{~V}$ & 24.5 & 0.38 & 67.6 \\
\hline & 75PV & 26.3 & 0.38 & 65.2 \\
\hline & 100PV & 26.6 & 0.40 & 66.2 \\
\hline & $75 \mathrm{PS}+\mathrm{V}$ & 26.5 & 0.38 & 66.0 \\
\hline & $100 P S+V$ & 22.6 & 0.35 & 68.4 \\
\hline & 75PS+PV & 26.0 & 0.38 & 66.2 \\
\hline & 100PS+PV & 25.6 & 0.36 & 66.1 \\
\hline & $75 V+P V$ & 25.5 & 0.38 & 67.2 \\
\hline & $100 V+P V$ & 24.3 & 0.34 & 67.1 \\
\hline
\end{tabular}


TABLE 8 (CONTINUED)

\begin{tabular}{|c|c|c|c|c|}
\hline Stage & $\begin{array}{c}\text { Irrigation Treatment } \\
\text { (stage+level) }\end{array}$ & Total soluble solids $\left({ }^{0} \mathrm{~B}\right)$ & $\begin{array}{c}\text { Soluble solid content/ } \\
\text { berry }(\mathrm{g})\end{array}$ & $\begin{array}{c}\text { Skin water } \\
(\%)\end{array}$ \\
\hline \multirow[t]{16}{*}{ H3 } & NI & 25.7 & 0.36 & 62.6 \\
\hline & 75All stages & 26.6 & 0.39 & 64.8 \\
\hline & 100All stages & 25.7 & 0.38 & 65.0 \\
\hline & 75PS & 28.6 & 0.38 & 61.4 \\
\hline & 100PS & 26.9 & 0.36 & 63.3 \\
\hline & $75 \mathrm{~V}$ & 28.2 & 0.40 & 62.1 \\
\hline & $100 \mathrm{~V}$ & 26.5 & 0.39 & 63.7 \\
\hline & 75PV & 28.0 & 0.40 & 62.9 \\
\hline & 100PV & 29.1 & 0.41 & 63.1 \\
\hline & 75PS+V & 26.9 & 0.34 & 63.4 \\
\hline & 100PS $+\mathrm{V}$ & 25.2 & 0.37 & 64.5 \\
\hline & 75PS+PV & 27.7 & 0.36 & 62.3 \\
\hline & 100PS+PV & 28.3 & 0.37 & 62.5 \\
\hline & $75 V+P V$ & 28.4 & 0.41 & 62.2 \\
\hline & $100 \mathrm{~V}+\mathrm{PV}$ & 26.2 & 0.37 & 64.3 \\
\hline & $\operatorname{LSD}(p=0.05)$ & 1.60 & 0.04 & 1.86 \\
\hline
\end{tabular}

PS = Pea size; $V=$ Véraison; PV = Post-véraison; $75=75 \%$ field water capacity irrigation; $100=100 \%$ field water capacity irrigation; $\mathrm{NI}=$ No irrigation; Trm. av. $=$ Treatment average; $\mathrm{H} 1=$ Harvest $1 ; \mathrm{H} 2=$ Harvest $2 ; \mathrm{H} 3=$ Harvest 3

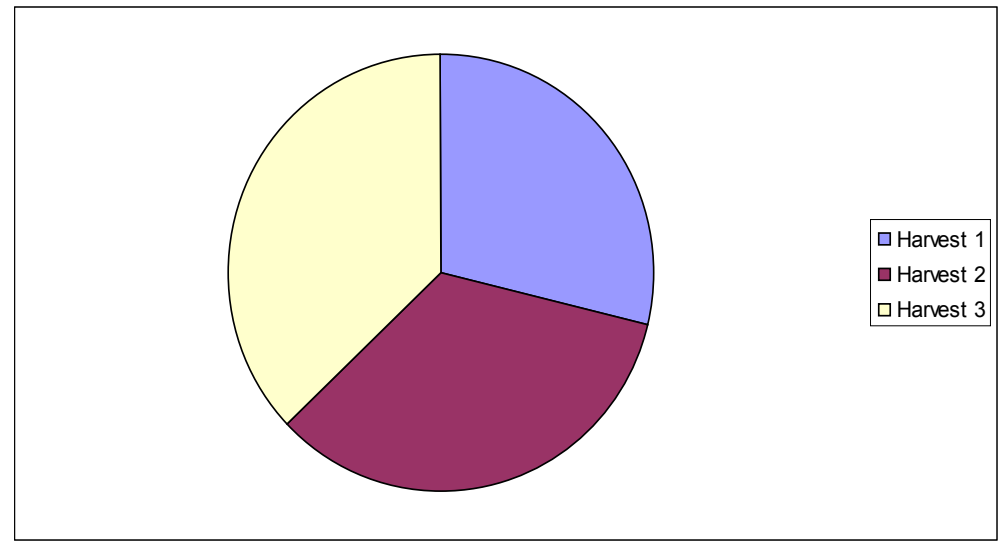

FIGURE 9

General effect (over level / stage of irrigation) on rachis:pulp+skin sucrose ratio of Shiraz/Richter 99 at different harvest stages.

It is well known that metabolic reaction is rather the result of hormonal cross-talk and interaction, e.g. between auxin and cytokinin, than individual hormonal action (Kamínek et al., 2006).

No less important in berry water relations is the role of semi-permeable membranes in the mesocarp cells (Tilbrook \& Tyerman, 2009; Fontes et al., 2011). Neither transpiration (suggested to be supported by night fluxes; being in accordance with diurnal VPD fluctuations; and a low stomatal density supporting a cuticular pathway of water loss - Greer \& Rogiers, 2009), phloem flow or xylem flow (whether partly or fully functional) (Lang \& Düring, 1991; Greenspan et al., 1994; Rebucci et al., 1997; Chatelet et al., 2008a, 2008b) seemed to be able to sustain influx during late ripening and to maintain berry turgor. Xylem backflow to the parent vine (Tyerman et al., 2004; Tilbrook \& Tyerman, 2009) may have been an accompanying possibility, at least through the central xylem bundles (Düring et al., 1987; Findlay et al., 1987; Lang \& Thorpe, 1989). The latter may even have contributed to a better maintenance of the rachis, as found in this study. If the hydraulic status of the parent plant is (largely) recovered and sucrose is building up in the leaves (albeit at a slow rate) during late ripening because of a decrease in active sink demand (Hunter et al., 1994), osmotic gradients would be expected to diminish in the phloem, and it may be argued that control for a cease in flow to the berry may be exerted by such mechanism, despite evidence that the vine is osmotically adjusting by increasing proline 
concentrations during this time (Matthews \& Anderson, 1988; Esteban et al., 2002; Hilbert et al., 2003).

For Shiraz, a physiological endpoint regarding sucrose demand by the berry seemed to occur during late ripening (Hunter et al., 2004). This was accompanied by a build-up of sucrose in the leaves, and preceded by a phloem-supported sucrose drain from the leaves and a physiological endpoint regarding active leaf function. Demand for sucrose by the rest of the plant, including the berry, seemed to continue during the senescing phase of the canopy, but a point was also clearly reached when active demand by the berry was terminated and reserve build-up was favoured. The build-up of sucrose in the leaves was judged to be the result of a low, but continuing, largely maintenance-orientated photosynthetic rate and a largely inactive sucrose-hydrolysing enzyme pool in the senescing tissue, i.e. both leaves and berries (Ruffner et al., 1990; Hunter et al., 1994; Hunter \& Ruffner, 2001), which led to a coordinated and regulated metabolic platform that was not supportive of phloem flux of water and sucrose.

Environmental conditions are changing late during ripening, with the senescing canopy having a lower evaporative demand during this time, photosynthetic output and concomitant loss of water by transpiration diminishing, sink demand on the canopy decreasing, sucrose building up in leaves, and the vine generally seeming at least to maintain water relations (Hunter et al., 1994; Hunter \& Ruffner, 2001; Hunter et al., 2004). It seems reasonable to assume that these events would lead to a reduction or balancing in the $\Psi$ gradient between the canopy/conduits of the parent plant and that of the berry, and that water flow and concomitant transport of sucrose to the berry would diminish, even under visually normal, intact bunch stem, rachis and pedicel occurrence. Sucrose loading and unloading of phloemtranslocated substances are bound to be affected. An osmotic gradient-driven mass transport to the berry (based on the hypothesis of passive phloem transport - Münch, 1930), created by osmotic differences between the vascular tissue and the berry mesocarp (see also Hunter \& Ruffner, 2001), may well be diminishing, particularly during late ripening. The Münch hypothesis relates to an influx and efflux of water, with a bulk flow of solution from source to sink that tends to balance solute concentrations through the passive mediation of water. Phloem sap is hydro-dynamically moved longitudinally under the force of pressure from the region of the source to that of the sink, changing its status from locally hyper-osmotic to locally hypo-osmotic, accommodating tube friction and losses on the way; major, active sources and sinks are most likely required for significant velocity (see also Pickard \& Abraham-Shrauner, 2009). It is argued that an apoplasmic route of sugar unloading is realised in ripening berries (Patrick, 1997), which may be preceded by a symplasmic route during the green berry phase (Zhang et al., 2006). However, under circumstances of saturated membrane transport (high sucrose concentrations in the free space), both apoplasmic and symplasmic routes may be operative during ripening, simultaneously or sequentially, depending on the conditions (Ho, 1988). The turnover rate of sucrolysis, particularly by the various forms of invertase (neutral, cytosolic, acid), may be critical to sustain the transfer of sucrose from sieve element/companion cell complexes in the berry brush (Hawker, 1985; Ruffner et al., 1990; Zhang et al., 2006). To prevent the dampening of phloem pressure and hence import into the berry, the depletion of apoplasmic sucrose must be offset by the maintenance of apoplasmic osmolarity (Lang \& Düring, 1991; Patrick, 1997). The unloading of sucrose into the berry apoplast would raise the osmotic pressure, causing water efflux from the phloem. This, in turn, would release the pressure in the phloem at the unloading site and phloem influx would result. The water released from the phloem would need to be transpired at a rate that would sustain gradients. It can be argued that the lack of strong gradients during late ripening would most likely reduce sucrose loading in sources (in the leaves into the phloem) and downloading at sinks (berries), despite the ostensibly still ample availability of sucrose in the leaves (see also Hunter et al., 2004). Transpiration seemed to outweigh the influx of sucrose during this time, hence the continued shrinking of the berry.

The relationship during early ripening between water influx (primarily via the phloem) and water efflux (via transpiration) apparently became weaker during late ripening (see also Etchebarne et al., 2007). During the latter period, water flux would seem rather to be physical/ non-metabolic (Dreier et al., 2000), with environmental factors playing a larger role in establishing final soluble solid concentration. This does not refrain from the complex regulatory processes involved in berry development, be they physically, fluxomically or metabolomically related. The osmotic potential of the berry is also not determined solely by sugar, but an array of compounds, including amino acids, organic acids, inorganic cations and anions, and other taste and flavour compounds, all contributing to the soluble solid/ osmotic status of the berry. Although partial degeneration seems more evident (Krasnow et al., 2008; Fontes et al., 2011), the viability of the internal structure of the berry (mesocarp cell integrity) changes during this time, be it because of compartmentation/membrane breakdown and/or cell death (Dreier et al., 1998; Tilbrook \& Tyerman, 2008), hence the decrease in firmness and observed shrivelling (Krasnow et al., 2008). According to Thomas et al. (2006), cell membranes (assumed plasmalemma and tonoplast) remain intact post-véraison [the difficulty is that few studies dealing with phloem transport, unloading, berry/cell integrity, etc. pinpoint the berry ripeness level, and it is mostly impossible to determine what exactly véraison/post-véraison/ripening/ early ripening/late ripening, etc. mean]. The apparent inability of the berry to maintain hydraulic vitality in distal parts versus proximal (brush) parts is evidence of osmotic imbalances and improper cell function (Tyerman et al., 2004). It can be assumed that these changes would be mainly turgor, cell wall matrix and membrane related (Dreier et al., 1998; Goulao \& Oliveira, 2008; Tilbrook \& Tyerman, 2009; Fontes et al., 2011). According to Nunan et al. (1998), no major changes in cell wall polysaccharide composition occurred during the softening of berries, but specific components were modified. Protein composition was largely affected, and the possibility of reinforcement of the cell walls with hydroxyproline-rich glycoproteins to maintain the integrity of mesocarp cells during softening was also mentioned. The pectin polymers in the cell walls consist of 
linear polygalacturonan chains (so-called smooth regions) interspersed with branched rhamnogalacturonan chains (socalled hairy regions), some of which are modified by methyl and/or acetyl esterification (Shevchik \& Hugouvieux-cottepattat, 2003). Although many factors are involved, the softening process is bound to be accompanied by enzyme activity, particularly endo- or exo-hydrolases capable of depolymerising the $(1 \rightarrow 4)$ - $\beta$-galactan constituents of the pectic polysaccharides and increasing their solubility through degradation (Nunan et al., 1998). Pectin methylesterases catalyse the hydrolysis of methyl-ester groups and control the accessibility of polygalacturonans to polygalacturonases and/or pectate lyases (Barnavon et al., 2000; Glissant et al., 2008). The rate of unloading therefore would be affected by the physiological and structural properties of the unloading pathway, in concert with sink metabolism/compartmentation. It seems evident that a scenario as described above may lead to a mixing of cytoplasm and vacuole contents, which would further affect taste, as well as the structure and flavour compounds of the berry at harvest via bonding, co-pigmentation, polymerisation and oxidation reactions. Although specifics are lacking at this stage, this may not necessarily be detrimental to wine quality.

It seems reasonable to assume that the vines in this study were not highly stressed and that ample water was available to sustain demands. The berries seemed to go through phases during the ripening period that resemble a change from a high to a low "sucrose plus water transport":"berry transpiration" ratio (Hunter et al., 2004). Active transport seemed to be followed by passive transport, which finally ceased under the ultimate influence of a diminishing driving force combining lower sucrose supply, lower phloem sucrose concentration, lower sucrose demand, decreasing sucrose metabolism/ compartmentation, low water potential gradients, reducing canopy and berry transpiration and changing (decreasing) atmospheric VPD. A continued loss of water from the berry finally led to a reduction in both mass and volume, which may be envisaged to lead to physicochemical changes. Late during ripening, berry size reduction was not sufficient to compensate for the diminishing inflow of sugar to the berry, leading to declining rates of accumulation of soluble solids. It seems evident that the berry water relations are largely independent of those of the parent plant, at least during late ripening (see also Chatelet et al., 2008; Greer \& Rogiers, 2009). This is also deductible from the observed patch of dead tissue in the brush region found by Fuentes et al. (2010). The water relations of the parent plant seem to be focused on maintenance and recovery requirements, as well as transport to and accumulation in reserve-building areas during this time. This is further accentuated by a passive and even non-existing demand by the berries.

Giving the lack of a clear soluble solid and berry volume response to late-season irrigation, the distribution of recently available sucrose during late ripening may have been redirected to areas of reserve accumulation. This may have been a physical, largely intra-vine water gradient-facilitated balancing flow of water (and concomitant sucrose flow into the phloem, despite the much reduced photosynthetic activity) that bypassed the berry, excluding the berry mesocarp in reestablishing a largely closed system focused on maintenance metabolism, displaying typical perennial behaviour. Although the use of reserve carbohydrate is not likely under conditions of ample canopy sucrose availability (CandolfiVasconcelos \& Koblet, 1990; Vasconcelos \& Castagnoli, 2000), a contribution to the phloem-located carbon pool for distribution to the berry, especially during late ripening (high ripeness level), should not be ignored and may also interfere with the debated canopy-berry relationships. In any event, the grape berry is (primarily) a sink organ that competes for solute partitioning priority right through the growth season by its (physical and metabolic) ability to attract water and solutes (Van Bel, 1993; Ho, 1988; Minchin et al., 1993; Patrick, 1997; Van Bel et al., 2013), under the influence of (often very demanding and unfavourable) environmental and cultivation conditions.

\section{CONCLUSIONS}

The water-holding capacity of the soil and changes in summer rainfall patterns from year to year within the high winter rainfall Mediterranean climate affected the reaction of the vines to treatments, complicating the data set and deductions and, in many cases, exerting an equalising effect. Yet, under the conditions of the terroir (with steep slope and expected deficit-inducing aspect) in which the grapevines were grown, additional water was still required and had a steering effect on physiological, vegetative and reproductive behaviour. Non-uniformity occurred in the duration of organ response and physiological response. Basic trends were in accordance with those found in other studies, whereas new information was obtained on the inter-relationships between the behaviour of the root system, canopy and grapes and changing terroir conditions (as affected by volume and timing of irrigation) during the ripening period.

The physical and compositional changes in the berry during late ripening under field conditions were clarified further. The study provided a further dimension to grapevine water relation effects on physiological behaviour and vegetative and reproductive growth, during grape ripening in particular. The effects of soil water on these multiple, interactive effects largely diminished as ripening proceeded. It is clear that soil water does not exert a direct causal effect, but rather an indirect effect, on grapevine physiological behaviour, steering a concert of processes within a whole plant system, under a strong influence of other environmental factors as the growth season progresses. This also confirms the complicating role that climate change and the expected exacerbated marginal abiotic conditions for grapevine cultivation may play in future interpretations of grapevine behaviour and grape and wine production.

\section{LITERATURE CITED}

Archer, E. \& Strauss, H.C., 1985. The effect of plant density on root distribution of three-year-old grafted 99 Richter grapevines. S. Afr. J. Enol. Vitic. 6, 25-30.

Barbagallo, M.G., Guidoni, S. \& Hunter, J.J., 2011. Berry size qualitative characteristics of Vitis vinifera L. cv. Syrah. S. Afr. J. Enol. Vitic. 32, 129-136.

Barnavon, L., Doco, T., Terrier, N., Ageorges, A., Romieu, C. \& Pellerin, P., 2000 . Analysis of cell wall neutral sugar composition, $\beta$-galactosidase activity and a related cDNA clone throughout the development of Vitis vinifera grape berries. Plant Physiol. Biochem. 38, 289-300. 
Bondada, B.R., Matthews, M.A. \& Shackel, K.A., 2005. Functional xylem in the post-véraison grape berry. J. Exp. Bot. 56, 2949-2957.

Candolfi-Vasconcelos, M.C. \& Koblet, W., 1990. Yield, fruit quality, bud fertility and starch reserves of the wood as a function of leaf removal in Vitis vinifera - evidence of compensation and stress recovering. Vitis 29, 199-221.

Chatelet, D.S., Rost, T.L. \& Shackel, K.A., 2008b. The peripheral xylem of grapevine (Vitis vinifera). 1. Structural integrity in post-véraison grape berries. J. Exp. Bot. 59, 1987-1996.

Chatelet, D.S., Rost, T.L., Matthews, M.A. \& Shackel, K.A., 2008a. The peripheral xylem of grapevine (Vitis vinifera) berries. 2. Anatomy and development. J. Exp. Bot. 59, 1997-2007.

Choné, X., Van Leeuwen, C, Dubourdieu, D. \& Gaudillère, J.-P., 2001. Stem water potential is a sensitive indicator of grapevine water status. Ann. Bot. $87,477-483$

Conde, C., Agasse, A., Glissant, D., Tavares, R., Geros, H. \& Delrot, S., 2006. Pathways of glucose regulation of monosaccharide transport in grape cells. Plant Physiol. 141, 1563-1577.

Coombe, B.G., 1987. Distribution of solutes within the developing grape berry in relation to its morphology. Am. J. Enol. Vitic. 38, 129-137.

Coombe, B.G., 1992. Research on development and ripening of the grape berry. Am. J. Enol. Vitic. 43, 101-110.

Creasy, G.L., Price, F. \& Lombard, P.B., 1993. Evidence for xylem discontinuity in Pinot noir and Merlot: Dye uptake and mineral composition during berry ripening. Am. J. Enol. Vitic. 44, 187-192.

Cyr, D. \& Shaw, T.B., 2010. The impact of global warming on Ontario's ice wine industry. In: VIII ${ }^{\text {th }}$ Int. Terroir Congress, June 2010, Soave, Italy. pp. 3-9-3-16.

Dal Santo, S., Tornielli, G.B., Zenoni, S., Fasoli, M., Farina, L., Anesi, A., Guzzo, F., Delledonne, M. \& Pezzotti, M., 2013. The plasticity of the grapevine berry transcriptome. Genome Biology 14, R54. doi: 10.1186/gb2013-14-6-r54.

Davies, C., Wolf, T. \& Robinson, S.P., 1999. Three putative sucrose transporters are differentially expressed in grapevine tissues. Plant Sci. 147, 93-100.

Deloire, A., Vaudour, E., Carey, V., Bonnardot, V. \& Van Leeuwen, C., 2005a. Grapevine responses and terroir: A global approach. J. Sci. Vigne Vin 39, 149162.

Deloire, A., Zebic, O., Bernard, N., Brenon, E. \& Hunter, J.J., 2005b. Influence de l'etat hydrique de la vigne sur le style de vin. Revue Fr. d'Oenologie 215, $11-15$.

Delrot, S., Picaud, S. \& Gaudillère, J.P., 2001. Water transport and aquaporins in grapevine. In: Roubelakis-Angelakis, K.A. (ed). Molecular biology and biotechnology of the grapevine. Kluwer Academic, Dordrecht. pp. 241 - 262.

Deluc, L.G., Grimplet, J., Wheatley, M.D., Tillet, R.L., Quilici, D.R., Osborne, C., Schooley, D.A., Schlauch, K.A., Cushman, J.C. \& Cramer, G.R., 2007. Transcriptomic and metabolite analyses of Cabernet Sauvignon grape berry development. BMC Genomics 8, 429. doi: 10.1186/1471-2164-8-429

Di Lorenzo, R., Barbagallo, M.G., Costanza, P., Gugliotta, E., Lino, T., Pisciotta A. \& Santangelo, T., 2005. Pre-dawn, stem and leaf water potential evolution in Vitis vinifera L. cv Nero d'Avola/1103 P under different water regime. Proc. $14^{\text {th }}$ GESCO Symp., August 2005, Geisenheim, Germany. pp. $493-498$.

Dreier, L.P., Hunter, J.J. \& Ruffner, H.P., 1998. Invertase activity, grape berry development and cell compartmentation. Plant Physiol. Biochem. 36, 865872 .

Dreier, L.P., Stoll, G.S. \& Ruffner, H.P., 2000. Berry ripening and evapotranspiration in Vitis vinifera L. Am. J. Enol. Vitic. 51, 340-346.
Düring, H., Lang, A. \& Oggionni, F., 1987. Patterns of water flow in Riesling berries in relation to developmental changes in their xylem morphology. Vitis 26, 123-131.

Escalona, J.M., Flexas, J. \& Medrano, H., 2002. Drought effects on water flow, photosynthesis and growth of potted grapevines. Vitis 41, 57-62.

Esteban, M.A., Villanueva, M.J. \& Lissarrague, J.R., 2002. Relationships between different berry components in Tempranillo (Vitis vinifera L.) grapes from irrigated and non-irrigated vines during ripening. J. Sci. Food Agric. 82, 1136-1146.

Etchebarne, F., Deloire, A., Ojeda, H., Lacapere, J.-N. \& Huallanca, D., 2007. Influence of grapevine water status on berry transpiration (Vitis vinifera L.; Grenache Noir). Proc. $15^{\text {th }}$ Int. GiESCO Symp., Porec, June 2007, Croatia, pp. $652-663$.

Etchebarne, F., Ojeda, H. \& Deloire, A., 2009. Influence of water status on mineral composition of berries in 'Grenache Noir' (Vitis vinifera). Vitis 48, 63-68.

Fillion, L., Ageorges, A., Picaud, S., Coutos-Thévenot, P., Lemoine, R., Romieu, C. \& Delrot, S., 1999. Cloning and expression of a hexose transporter gene expressed during the ripening of grape berry. Plant Physiol. 120, 10831094.

Findlay, N., Oliver, K.J., Nii, N. \& Coombe, B.G., 1987. Solute accumulation by grape pericarp cells. J. Exp. Bot. 38, 668-679.

Fontes, N., Gerós, H. \& Delrot, S., 2011. Grape berry vacuole: A complex and heterogeneous membrane system specialized in the accumulation of solutes. Am. J. Enol. Vitic. 62, 270-278.

Fouquet, R., Léon, C., Ollat, N. \& Barrieu, F., 2008. Identification of grapevine aquaporins and expression analysis in developing berries. Plant Cell Rep. 27, 1541-1550.

Fuentes, S., Sullivan, W., Tilbrook, J. \& Tyerman, S., 2010. A novel analysis of grapevine berry tissue demonstrates a variety-dependent correlation between tissue vitality and berry shrivel. Austr. Soc. Vitic Oenology, 327-336.

Glissant, D., Dédaldéchamp, F. \& Delrot, S., 2008. Transcriptomic analysis of grape berry softening during ripening. J. Int. Sci. Vigne Vin 42, 1-13.

Goulao, L.F. \& Oliveira, C.M., 2008. Cell wall modifications during fruit ripening: when a fruit is not the fruit. Trends in Food Sci. \& Techn. 19, 4-25.

Greenspan, M.D., Schultz, H.R. \& Matthews, M.A., 1996. Field evaluation of water transport in grape berries during water deficits. Physiol. Plant. 97, $55-62$.

Greenspan, M.D., Shackel, K.A. \& Matthews, M.A., 1994. Developmental changes in the diurnal water budget of the grape berry exposed to water deficits. Plant Cell Environ. 17, 811-820.

Greer, D.H. \& Rogiers, S.Y., 2009. Water flux of Vitis vinifera L. cv. Shiraz bunches throughout development and in relation to late-season weight loss. Am. J. Enol. Vitic. 60, 155-163.

Harholt, J., Suttangkakul, A. \& Scheller, H.V., 2010. Biosynthesis of pectin. Plant Physiol. 153, 384-395.

Hawker, J.S., 1985. Sucrose. In: Dey, P.M. \& Dixon, R.A. (eds). Biochemistry of storage carbohydrates in green plants. Academic Press, London, pp. $1-55$.

Hilbert, G., Soyer, J.P., Molot, C., Giraudon, J., Milin, S. \& Gaudillère, J.P., 2003. Effects of nitrogen supply on must quality and anthocyanin accumulation in berries of cv. Merlot. Vitis 42, 69-76.

Hiratsuka, S., Onodera, H., Kawai, Y., Kubo, T., Itoh, H. \& Wada, R., 2001. $\mathrm{ABA}$ and sugar effects on anthocyanin formation in grape berry cultured in vitro. Sci. Hort. 90, 121-130.

Ho, L.C., 1988. Metabolism and compartmentation of imported sugars in sink organs in relation to sink strength. Ann. Rev. Plant Physiol. Plant Mol. Biol. $38,355-378$ 
Hunter, J.J., 1998a. Plant spacing implications for grafted grapevine I. Soil characteristics, root growth, dry matter partitioning, dry matter composition and soil utilisation. S. Afr. J. Enol. Vitic. 19, 25-34.

Hunter, J.J., 1998b. Plant spacing implications for grafted grapevine II. Soil water, plant water relations, canopy physiology, vegetative and reproductive characteristics, grape composition, wine quality and labour requirements. S. Afr. J. Enol. Vitic. 19, 25-34.

Hunter, J.J., 2000. Implications of seasonal canopy management and growth compensation in grapevine. S. Afr. J. Enol. Vitic. 21, 81-91.

Hunter, J.J. \& Bonnardot, V., 2002. Climatic requirements for optimal physiological processes: A factor in viticultural zoning. In: Proc. IV th Int Symp. on Viticultural Zoning, June 2002, Avignon, France. pp. 553 - 565.

Hunter, J.J. \& Bonnardot, V., 2011. Suitability of some climatic parameters for grapevine cultivation in South Africa, with focus on key physiological processes. S. Afr. J. Enol. Vitic. 32, 137-154.

Hunter, J.J. \& Deloire, A., 2005. Relationship between sugar loading and berry size of ripening Syrah/R99 grapes as affected by grapevine water status. Proc. $14^{\text {th }}$ GESCO Symp., August 2005, Geisenheim, Germany. pp. $127-133$.

Hunter, J.J. \& Myburgh, P., 2001. Ecophysiological basis for water management of vineyards in South Africa, with particular reference to environmental limitations. In: Proc. $12^{\text {th }}$ GESCO Symp., July 2001, Montpellier, France. pp. $23-43$.

Hunter, J.J. \& Ruffner, H.P., 2001. Assimilate transport in grapevines effect of phloem disruption. Aust. J. Grape Wine Res. 7, 118-126.

Hunter, J.J. \& Visser, J.H., 1988. Distribution of ${ }^{14} \mathrm{C}$-Photosynthetate in the shoot of Vitis vinifera L. cv. Cabernet Sauvignon. I. The effect of leaf position and developmental stage of the vine. S. Afr. J. Enol. Vitic. 9, 3-9.

Hunter, J.J. \& Visser, J.H., 1989. The effect of partial defoliation, leaf position and developmental stage of the vine on leaf chlorophyll concentration in relation to the photosynthetic activity and light intensity in the canopy of Vitis vinifera L. cv. Cabernet Sauvignon. S. Afr. J. Enol. Vitic. 10, 67-73.

Hunter, J.J. \& Visser, J.H., 1990. The effect of partial defoliation on growth characteristics of Vitis vinifera L. cv. Cabernet Sauvignon. I. Vegetative growth. S. Afr. J. Enol. Vitic. 11, 18-25.

Hunter, J.J., Archer, E. \& Volschenk, C.G., 2010. Vineyard management for environment valorisation. In: VIII'th ${ }^{\text {th }}$ In. Terroir Congress, June 2010, Soave, Italy. pp. 7-3 - 7-15

Hunter, J.J., Archer, E., Strever, A. \& Volschenk, C.G., 2011. Integrative strategies for sustainable viticulture and terroir valorisation. Proc. $17^{\text {th }}$ GiESCO Symp., Aug./Sept. 2011, Asti-Alba, Italy. pp. 73 - 78.

Hunter, J.J., De Villiers, O.T. \& Watts, J.E., 1991. The effect of partial defoliation on quality characteristics of Vitis vinifera L. cv. Cabernet Sauvignon grapes. II. Skin colour, skin sugar, and wine quality. Am. J. Enol. Vitic. 42, 13-18.

Hunter, J.J., Pisciotta, A., Voschenk, C.G., Archer, E., Novello, V., Deloire, A. \& Nadal, M., 2004. Role of harvesting time/optimal ripeness in zone/ terroir expression. In: Proc. Joint Conference (SASEV, OIV, GESCO) on Viticultural Zoning, November 2004, Cape Town, South Africa. pp. $466-$ 478.

Hunter, J.J., Ruffner, H.P., Volschenk, C.G. \& Le Roux, D.J., 1995. Partial defoliation of Vitis vinifera L. cv. Cabernet Sauvignon/99 Richter: Effect on root growth, canopy efficiency, grape composition and wine quality. Am. J. Enol. Vitic. 46, 306-314.

Hunter, J.J., Skrivan, R. \& Ruffner, H.P., 1994. Diurnal and seasonal physiological changes in leaves of Vitis vinifera $\mathrm{L}$.: $\mathrm{CO}_{2}$ assimilation rates, sugar levels and sucrolytic enzyme activity. Vitis 33, 189-195.
Kamínek, M., Ludwig-Müller, J., Vanková, R. \& Zazímalová, E., 2006. Auxins and cytokinins in plant development. J. Plant Growth Regul. 25, 89-97.

Keller, M., Smith, J.P. \& Bondada, B.R., 2006. Ripening grape berries remain hydraulically connected to the shoot. J. Exp. Bot. 11, 2577-2587.

Krasnow, M., Matthews, M. \& Shackel, K.A., 2008. Evidence for substantial maintenance of membrane integrity and cell viability in normally developing grape (Vitis vinifera L.) berries throughout development. J. Exp. Bot. 59, 849-859.

Lang, A. \& Düring, H., 1991. Partitioning control by water potential gradient: Evidence for compartmentation breakdown in grape berries. J. Exp. Bot. 42, 1117-1122.

Lang, A. \& Thorpe, M.R., 1989. Xylem, phloem and transpiration flows in a grape: Application of a technique to measure the volume of attached fruits to high resolution Archimedes' principle. J. Exp. Bot. 40, 1069-1078.

Little, T.M. \& Hills, F.J., 1978. Agricultural experimentation: Design and Analysis. Wiley, New York, 125-137.

Lovisolo, C., Hartung, W. \& Schubert, A., 2002. Whole-plant hydraulic conductance and root-to-shoot flow of abscisic acid are independently affected by water stress in grapevines. Funct. Plant Biol. 29, 1349-1356.

Lovisolo, C., Perrone, I., Carra, A., Ferrandino, A., Flexas, J., Medrano, H. \& Schubert, A., 2010. Drought-induced changes in development and function of grapevine (Vitis spp.) organs and in their hydraulic and non-hydraulic interactions at the whole-plant level: A physiological and molecular update. Funct. Plant Biol. 37, 98-116.

Matthews, M.A. \& Anderson, M.M., 1988. Fruit ripening in Vitis vinifera L.: Responses to seasonal water deficits. Am. J. Enol. Vitic. 39, 313-320.

McCarthy, M.G., 1999. Weight loss from ripening berries of Shiraz grapevines (Vitis vinifera L. cv. Shiraz). Aust. J. Grape Wine Res. 5, 10-16.

McCarthy, M.G. \& Coombe, B.G., 1999. Is weight loss in ripening grape berries cv. Shiraz caused by impeded phloem transport. Aust. J. Grape Wine Res. 5, 17-21.

Minchin, P.E.H., Thorpe, M.R. \& Farrar, J.F., 1993. A simple mechanistic model of phloem transport which explains sink priority. J. Exp. Bot. 44, 947- 955 .

Mohr, H. \& Schopher, P., 1995 (4th ed.). Plant physiology. Springer-Verlag, Berlin.

Mpelasoka, B.S., Schachtman, D.P., Treeby, M.T. \& Thomas, M.R., 2003. A review of potassium nutrition in grapevines. Aust. J. Grape Wine Res. 9 , 154-168.

Münch, E., 1930. Die stoffbewegungen in der Pflanze. Gustav Fischer, Germany.

Myburgh, P.A., 2005. Water status, vegetative growth and yield responses of Vitis vinifera L. cvs. Sauvignon blanc and Chenin blanc to timing of irrigation during berry ripening in the coastal region of South Africa. S. Afr. J. Enol. Vitic. 26, 59-67.

Naor, A. \& Wample, R.L., 1994. Gas exchange and water relations of fieldgrown Concord (Vitis labruscana Bailey) grapevines. Am. J. Enol. Vitic. $45,333-337$.

Novello, V. \& Hunter, J.J., 2004. Canopy photosynthetic activity and water relations of Syrah/R99 as affected by row orientation on a particular terroir. In: Proc. Joint Conf. (SASEV, OIV, GESCO) on Viticultural Zoning, November 2004, Cape Town, South Africa. pp. 452 - 459.

Nunan, K.J., Sims, I.M., Bacic, A., Robinson, S.P. \& Fincher, G.B., 1998. Changes in cell wall composition during ripening of grape berries. Plant Physiol. 118, 783-792. 
Ojeda, H., Andary, C., Kraeva, E., Carbonneau, A. \& Deloire, A., 2002. Influence of pre- and postveraison water deficit on synthesis and concentration of skin phenolic compounds during berry growth of Vitis vinifera cv. Shiraz. Am. J. Enol. Vitic. 53, 261-267.

Ott, R.L., 1998. An introduction to statistical methods and data analysis. Duxbury Press, Belmont, California.

Patakas, A. \& Noitsakis, B., 1999. Mechanisms involved in diurnal changes of osmotic potential in grapevines under drought conditions. J. Plant Physiol. 154, 767-774.

Patakas, A., Noitsakis, B. \& Chouzouri, A., 2005. Optimization of irrigation water use in grapevines using the relationship between transpiration and plant water status. Agric. Ecosyst. Environ. 106, 253-259.

Patakas, A., Noitsakis, B. \& Stavrakas, D., 1997. Adaptation to seasonal drought in Vitis vinifera L. as affected by leaf age. Vitis $36,11-14$.

Patrick, J.W., 1997. Phloem unloading: Sieve element unloading and postsieve element transport. Ann. Rev. Plant Physiol. Plant Mol. Biol. 48, 191222 .

Pickard, W.F. \& Abraham-Shrauner, B., 2009. A "simplest" steady-state Münch-like model of phloem translocation, with source and pathway and sink. Functional Plant Biol. 36, 629-644.

Pratelli, R., Lacombe, B., Torregrosa, L., Gaymard, F., Romieu, C., Thibaud, J.-B. \& Sentenac, H., 2002. A grapevine gene encoding a guard cell $\mathrm{K}^{+}$channel displays developmental regulation in the grapevine berry. Plant Physiol. 128, 564-577.

Quiroga, A.M., Berli, F.J., Moreno, D., Cavagnaro, J.B. \& Bottini, R., 2009. Abscisic acid sprays significantly increase yield per plant in vineyardgrown wine grape (Vitis vinifera L.) cv. Cabernet Sauvignon through increased berry set with no negative effects on anthocyanin content and total polyphenol index of both juice and wine. J. Plant Growth Regul. 28, 28-35.

Rebucci, B., Poni, S., Intrieri, C., Magnanini, E. \& Lakso, A.N., 1997. Effects of manipulated grape berry transpiration on post-véraison sugar accumulation. Aust. J. Grape Wine Res. 3, 57-65.

Richards, D., 1983. The grape root system. Hortic. Rev. 5, 127-168.

SAS Institute, Inc., 2008. SAS Version 9.2. SAS Institute Inc, SAS Campus Drive, Cary, North Carolina 27513.

Roby, G. \& Matthews, M.A., 2004. Relative proportions of seed, skin and flesh, in ripe berries from Cabernet Sauvignon grapevines grown in a vineyard either well irrigated or under water deficit. Aust. J. Grape Wine Res. $10,74-82$.

Rogiers, S.Y., Greer, D.H., Hatfield, J.M., Orchard, B.A. \& Keller, M., 2006. Solute transport into Shiraz berries during development and lateripening shrinkage. Am. J. Enol. Vitic. 57, 73-80.

Rogiers, S.Y., Keller M., Holzapfel, B.P. \& Virgona, J.M., 2000. Accumulation of potassium and calcium by ripening berries on field vines of Vitis vinifera (L.) cv. Shiraz. Aust. J. Grape Wine Res. 6, 240-243.

Rogiers, S.Y., Smith, J.S., White, R., Keller M., Holzapfel, B.P. \& Virgona, J.M., 2001. Vascular function in berries of Vitis vinifera (L.) cv. Shiraz. Aust. J. Grape Wine Res. 7, 47-51.

Ruffner, H.P., Adler, S. \& Rast, D.M., 1990. Soluble and wall associated forms of invertase in Vitis vinifera. Phytochem. 29, 2083-2086.

SAS, 2012. SAS Version 9.2., SAS Institute Inc, Cary, North Carolina 27513 .

Schaller, K., Löhnertz, O. \& Chikkasubbanna, V., 1992. Uptake of potassium by the grape berries of different cultivars during growth and development. Vitic. Enol. Sci. 47, 36-39.
Scholander, P.F., Hammel, H.T., Bradstreet, E.D. \& Hemmingsen, E.A., 1965. Sap pressure in vascular plants. Science 148, 339-346.

Schultz, H.R., 2000. Climate change and viticulture: A European perspective on climatology, carbon dioxide and UV-B effects. Aust. J. Grape Wine Res. 6, 2-12.

Schultz, H.R. \& Matthews, M.A., 1988. Resistance to water transport in shoots of Vitis vinifera L. Plant Physiol. 88, 718-724.

Schultz, H.R. \& Stoll, M., 2010. Some critical issues in environmental physiology of grapevines: Future challenges and current limitations. Aust. J. Grape Wine Res. 16, 4-24.

Shapiro, S.S. \& Wilk, M.B., 1965. An analysis of variance test for normality (complete samples). Biometrika 52, 591-611.

Shevchik, V. E. \& Hugouvieux-Cotte-Pattat, N., 2003. PaeX, a second pectin acetylesterase of Erwinia chrysanthemi 3937. J. Bacteriol. 185, 30913100 .

Smart, R.E. \& Coombe, B.G., 1983. Water relations of grapevines. In: Kozlowski, T.T. (ed.). Water deficits and plant growth. Vol 7. Academic Press, New York, pp. $137-196$.

Soil Classification Working Group, 1991. Soil classification - A taxonomic system for South Africa. Department of Agricultural Development: Memoirs on natural agricultural resources of South Africa No. 15. Department of Agricultural Development, Pretoria.

Swanepoel, J.J. \& Southey, J.M., 1989. The influence of rootstock on the rooting pattern of the grapevine. S. Afr. J. Enol. Vitic. 10, 23-28.

Thomas, T.R., Matthews, M.A. \& Shackel, K.A., 2006. Direct in situ measurement of cell turgor in grape (Vitis vinifera L.) berries during development and in response to plant water deficits. Plant, Cell and Environ. 29, 993-1001.

Tilbrook, J. \& Tyerman, S.D., 2008. Cell death in grape berries: Varietal differences linked to xylem pressure and berry weight loss. Funct. Plant Biol. 35, 173-184.

Tilbrook, J. \& Tyerman, S.D., 2009. Hydraulic connection of grape berries to the vine: Varietal differences in water conductance into and out of berries, and potential for backflow. Funct. Plant Biol. 36, 541-550.

Tyerman, S.D., Niemietz, C.M. \& Bramley, H., 2002. Plant aquaporins: Multifunctional water and solute channels with expanding roles. Plant Cell Environ. 125, 173-194.

Tyerman, S.D., Tilbrook, J., Pardo, C., Kotula, L., Sullivan, W. \& Steudle, E., 2004. Direct measurement of hydraulic properties in developing berries of Vitis vinifera L. cv. Shiraz and Chardonnay. Aust. J. Grape Wine Res. 10, 170-181.

Van Bel, A.J.E., 1993. Strategies of phloem loading. Ann. Rev. Plant Physiol. Plant Mol. Biol. 44, 253-281.

Van Bel, A.J.E., Helariutta, Y., Thompson, G.A., Ton, J., Dinant, S., Ding, B. \& Patrick, J.W., 2013. Phloem: the integrative avenue for resource distribution, signalling, and defense. Front. Plant Sc. 4, 1-3.

Vasconcelos, M.C. \& Castagnoli, S., 2000. Leaf canopy structure and vine performance. Am. J. Enol. Vitic. 51, 390-396.

Vaudour E., 2003. Les terroirs viticoles. Définitions, caractérisation, protection. Ed. Dunod, Paris.

Wheeler, S., Loveys, B., Ford, C. \& Davies, C., 2009. The relationship between the expression of abscisic acid biosynthesis genes, accumulation of abscisic acid and the promotion of Vitis vinifera L. berry ripening by abscisic acid. Aust. J. Grape Wine Res. 15, 195-204. 
Williams, L.E. \& Matthews, M.A., 1990. Grapevine. In: Stewart, B.A. \& Nielsen, D.R. (eds). Irrigation of agricultural crops. Agronomy monograph No. 30. Madison: ASA-CSSA-SSSA. pp. 1019 - 1055.

Yu, X.-C., Li, M.-J., Gao, G.-F., Feng, H.-Z., Geng, X.-Q., Peng, C.-C., Zhu, S.-Y., Wang, X.-J., Shen, Y.-Y. \& Zhang, D.-P., 2006. Abscisic acid stimulates a calcium-dependent protein kinase in grape berry. Plant Physiol. $140,558-579$
Zhang, X.Y., Wang, X.L., Wang, X.F., Xia, G.H., Pan, Q.H., Fan, R.C., Wu, F.Q., Wu, X.C. \& Zhang, D.P., 2006. A shift of phloem unloading from symplasmic to apoplasmic pathway is involved in developmental onset of ripening in grape berry. Plant Physiol. 142, 220-232.

Zhang, Y.L., Meng, Q.Y., Zhu, H.L., Guo, Y., Gao, H.Y., Luo, Y.B. \& Lu, J., 2008. Functional characterisation of a LAHC sucrose transporter isolated from grape berries in yeast. Plant Growth Reg. 54, 71-79. 